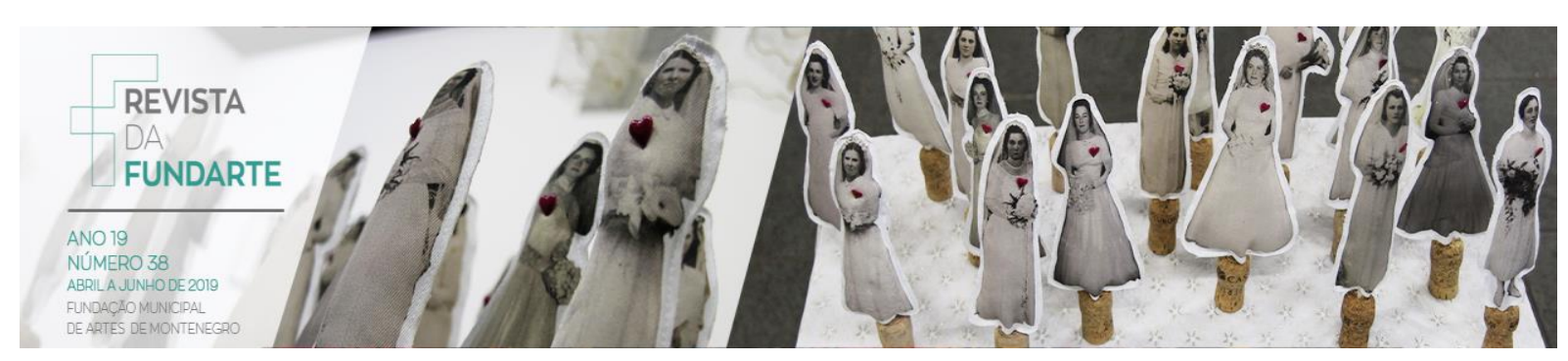

\title{
A MÚSICA NA REVISTA DA FUNDARTE: CONTRIBUIÇÕES PARA O PENSAMENTO EDUCATIVO-MUSICAL
}

\author{
Bruno Felix da Costa Almeida ${ }^{1}$ \\ Cristina Rolim Wolffenbüttel${ }^{2}$
}

\begin{abstract}
Resumo: O estudo apresenta o "estado da arte" na Revista da FUNDARTE, em se tratando da linguagem em Arte-Música, e suas possíveis articulações ao campo educativo-musical. O referencial teórico consiste nos pressupostos de Kraemer (2000) sobre os usos e funções do conhecimento pedagógico-musical. A metodologia utilizada inclui as abordagens Quali-quantitativa, e a Análise de Discurso, enquanto método. Para a análise dos dados, a Análise de Conteúdo. A diversidade das temáticas em Música publicadas nos 87 textos selecionados na Revista da FUNDARTE possibilitou a compreensão da importância da articulação dos conhecimentos gerais em Música às perspectivas educativo-musicais, em prol de uma reflexão abrangente ao campo da Educação Musical contemporânea.
\end{abstract}

Palavras-chave: Música; Educação Musical; Pesquisa Estado da Arte.

\section{THE MUSIC OF FUNDARTE MAGAZINE: CONTRIBUTIONS TO THE EDUCATIONAL AND MUSICAL THOUGHT}

\begin{abstract}
The study presents the "State of the art" in the Magazine of FUNDARTE, in the case of language in Art-Music, and its possible joints to educational-musical field. The theoretical reference consists of the Kraemer (2000) assumptions about the uses and functions of pedagogic-musical knowledge. The methodology includes the Quali-quantitative approaches, and in the analysis of discourse, while method. For data analysis, content analysis. The diversity of themes in music published in selected texts in 87 in the Magazine of FUNDARTE enabled the understanding of the importance of the articulation of the general knowledge in music education-musical, prospects for a reflection comprehensive to the field of music education.
\end{abstract}

Keywords: Music; Music Education; State of the Art Research.

\footnotetext{
${ }^{1}$ Especialista em Educação Musical pela Universidade Estadual do Rio Grande do Sul (2016) e em Ensino de Arte pela Universidade Cidade de São Paulo (2015); Bacharel em Música - Habilitação em Piano, pelo Núcleo de Música da Universidade Cruzeiro do Sul (2010), onde estudou com bolsa de estudos por mérito acadêmico; Formado em Piano pela Escola Municipal de Música - Departamento do Theatro Municipal de São Paulo (2012) e em Teclado pelo Conservatório Musical In'Concert (2002); Atualmente é acadêmico dos cursos de Mestrado Profissional em Educação e Graduação em Música: Licenciatura, da Universidade Estadual do Rio Grande do Sul; além de desenvolver pesquisas na área de Educação, Educação Musical, Psicologia da Aprendizagem e Políticas Educacionais.

2 Pós-Doutora, Doutora e Mestre em Educação Musical pela Universidade Federal do Rio Grande do Sul. Especialista em Informática na Educação Ênfase em Instrumentação, pela Pontifícia Universidade Católica do Rio Grande do Sul. Licenciada em Música pela Universidade Federal do Rio Grande do Sul. Coordenadora do curso de Especialização em Educação Musical na Universidade Estadual do Rio Grande do Sul, Unidade de Montenegro. Professora do Programa de Pós-Graduação em Educação da Universidade Estadual do Rio Grande do Sul. Líder dos grupos de pesquisa registrados no CNPq/UERGS "Arte: criação, interdisciplinaridade e educação" e "Educação Musical: diferentes tempos e espaços". Diretora Científica da Coleção Educação Musical, da Editora Prismas, de Curitiba. Coordenadora da política de leitura na Secretaria Municipal de Educação de Porto Alegre/RS.
}

ALMEIDA, Bruno Felix da Costa; WOLFFENBÜTTEL, Cristina Rolim. A música na Revista da FUNDARTE: contribuições para o pensamento educativo-musical. Revista da FUNDARTE, Montenegro, p.117-163, ano 19, nº 38, abril/junho de 2019.

Disponível em: http://.seer.fundarte.rs.gov.br/index.php/RevistadaFundarte/index> 28 de junho de 2019. 


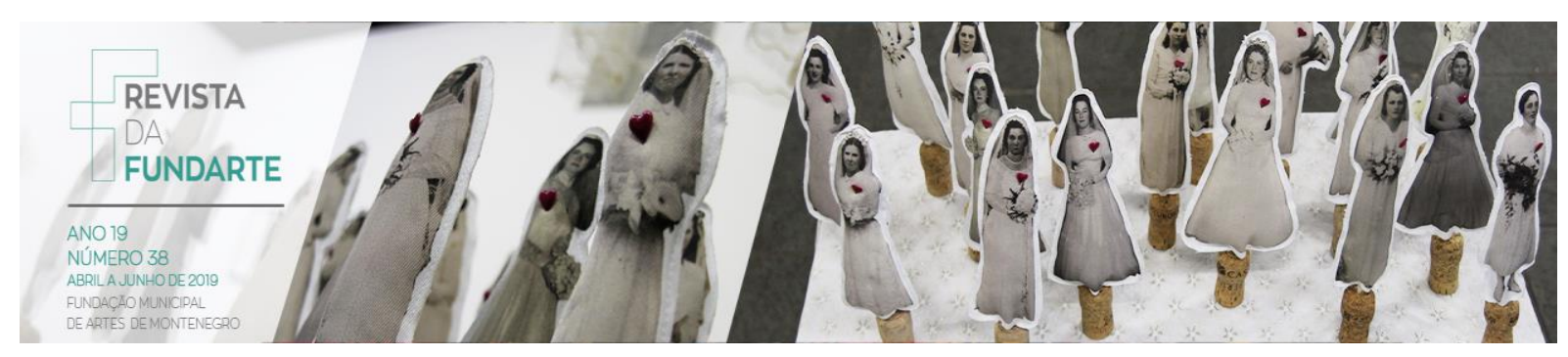

\section{Introdução}

Criada em 2001 com o intuito de viabilizar um espaço acadêmico de discussão sobre a temática "Arte, Educação e Performance", a Revista da FUNDARTE (RDF) é publicada semestralmente com artigos "resultantes de estudos teóricos, pesquisas e reflexões sobre práticas artísticas e docentes, nas quatro áreas das Artes: Artes Visuais, Dança, Música e Teatro" (SITE REVISTA DA FUNDARTE, 2019).

Em compreendendo a importância desse periódico para pesquisadores em Arte e Educação, emergiram alguns questionamentos, os quais nortearam o processo investigativo empreendido, quais sejam: Em quais edições da RDF, publicadas entre janeiro de 2001 a dezembro de 2018, estão presentes os artigos sobre Música? Quais as temáticas tratadas nos artigos? Qual a contribuição da produção publicada na RDF para a Educação Musical?

Portanto, o foco central desse estudo foi compreender como os conhecimentos em Música, publicados na RDF, podem contribuir ao pensamento educativo-musical na contemporaneidade. Não obstante a esta centralidade, a identificação e a análise dos textos sobre Música, bem como as temáticas e os principais aspectos vinculados a estes, também se constituíram objetivos desta investigação.

Compreende-se, também, que as informações derivadas do estudo podem contribuir à importância de se articular conhecimentos oriundos de diversas áreas das ciências humanas, tais como da antropologia, da filosofia, da história, da pedagogia, da sociologia, dentre outras, ao conhecimento musical, considerando a transversalidade das informações para a configuração e compreensão do campo educativo-musical.

Pesquisas que se propõem a construir um panorama sobre as investigações científicas realizadas em uma determinada área e/ou assunto, por exemplo, são denominadas de "Estado da Arte", o que, de certa forma, configura uma das proposições deste estudo. Ferreira (2002) explica que investigações deste cunho 


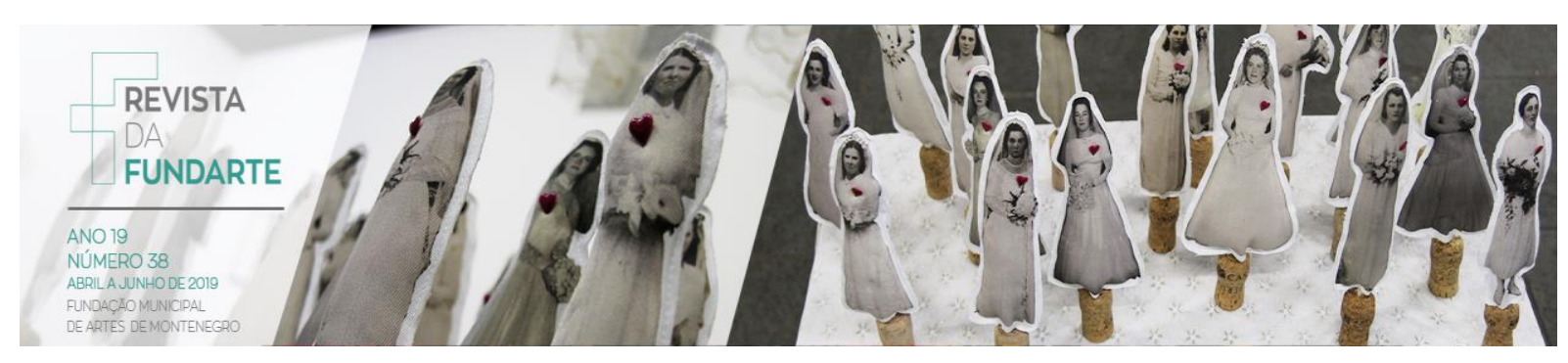

[...] parecem trazer em comum o desafio de mapear e de discutir uma certa produção acadêmica em diferentes campos do conhecimento, tentando responder que aspectos e dimensões vêm sendo destacado e privilegiados em diferentes épocas e lugares, de que formas e em que condições têm sido produzidas certas dissertações de mestrado, teses de doutorado, publicações em periódicos e comunicações em anais de congressos e de seminários. (FERREIA, 2002, p. 258).

Por sua vez, Romanowski e Ens (2006), relatam a incidência da realização de estudos sobre o "estado da arte" na área da educação no Brasil, sendo estas contribuições relevantes à comunidade científica preocupada sobre o que se tem realizado de estudos nesse campo.

Em se tratando da Educação Musical, o "estado da arte" da Educação Musical tem interessado os pesquisadores da área. Pires e Dalben (2013), por exemplo, investigaram a temática, tendo como foco a Revista da ABEM. Aquino (2017) também realizou pesquisa semelhante, incluindo as revistas Música na Educação Básica, a Revista da ANPPOM (Opus), além da própria Revista da ABEM.

Nesse sentido, são relacionados, a seguir, os procedimentos metodológicos adotados à realização deste estudo, precedidos pelas seções Teoria e Referência, a qual trata do referencial teórico analítico selecionado à leitura e interpretação dos dados coletados; A Música na Revista da FUNDARTE, que apresenta o estado da arte em Música na RDF; e, por fim, em Contribuições para o Pensamento Educativomusical, são apresentadas as reflexões sobre a música na RDF transversalizadas ao referencial teórico selecionado.

\section{Procedimentos Metodológicos}

Para o desenvolvimento desta pesquisa, fez-se uso da abordagem qualitativa - pois, como explicam Bauer, Gaskell e Allum (2015), viabiliza "uma visão mais holística do processo de pesquisa social" (p.26) - e quantitativa, estabelecendo relações numéricas a partir dos dados coletados (MINAYO, 2013).

Enquanto método investigativo, a análise de discurso proposta por Gill (2015) se apresentou a mais pertinente. Conforme pressupõe a autora: 


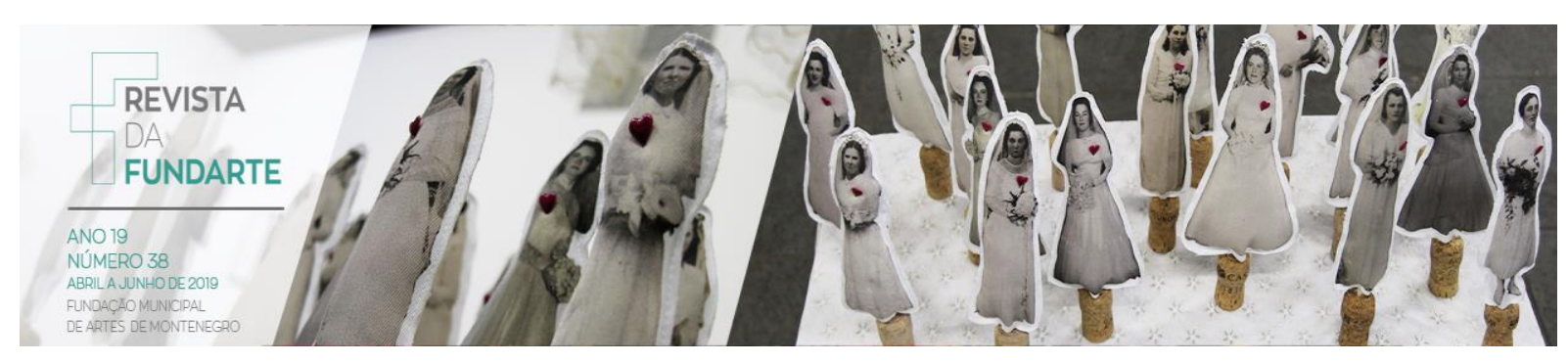

É proveitoso pensar na análise de discurso como tendo quatro temas principais: uma preocupação com o discurso em si mesmo; uma visão da linguagem como construtiva (criadora) e construía; uma ênfase no discurso como uma forma de ação; e uma convicção na organização retórica do discurso. (GILL, 2015, p. 247).

Para a composição do corpus de análise, a pesquisa via Internet, na perspectiva de Koch (1995), foi considerada como a mais adequada. Para Koch (1996), esta modalidade de coleta de dados possibilita ao investigador a realização de três procedimentos-padrão: surfing (busca por links na Internet) que, para esta investigação, configurou o acesso ao repositório virtual da RDF; browsing (o folhear da página da Internet acessada), que consistiu em acessar o sumário de cada um dos números da RDF publicados de janeiro de 2001 a dezembro de 2018; e searching (busca avançada por palavras dentro do site), ou seja, a busca por títulos dos sumários que pudessem remeter à Música, e, posteriormente, por termos nos resumos e/ou palavras-chave nos artigos, ambas vinculadas à área da Música.

Para a análise dos dados coletados foram utilizadas as cinco etapas para a análise de conteúdo propostas por Moraes (1999, p. 2), no intuito de "descrever e interpretar o conteúdo" dos textos coletados. Portanto, os dados foram: 1 Preparados (procedimento que viabilizou a codificação de todos os textos selecionados em ordem numérica de 1 a 87); 2 - Unitarizados (os dados foram lidos e identificados com termos-chave); 3 - Categorizados (os termos-chave deram origem às categorias de análise) - as categorias elaboradas correspondem a cada um dos subtítulos relacionados na seção intitulada "Música na Revista da FUNDARTE"; 4 - Descritos (cada um dos 87 textos selecionados foi resumido, apontando seus principais aspectos); e, por fim, 5 - Interpretação (procedimento que auxiliou na construção da análise e das considerações finais do estudo). Salienta-se que para esta coleta de dados os resumos e as palavras-chaves foram lidos, bem como, quando necessário - na ausência de informações substanciais para a realização deste estudo - os textos foram lidos integral ou parcialmente. 


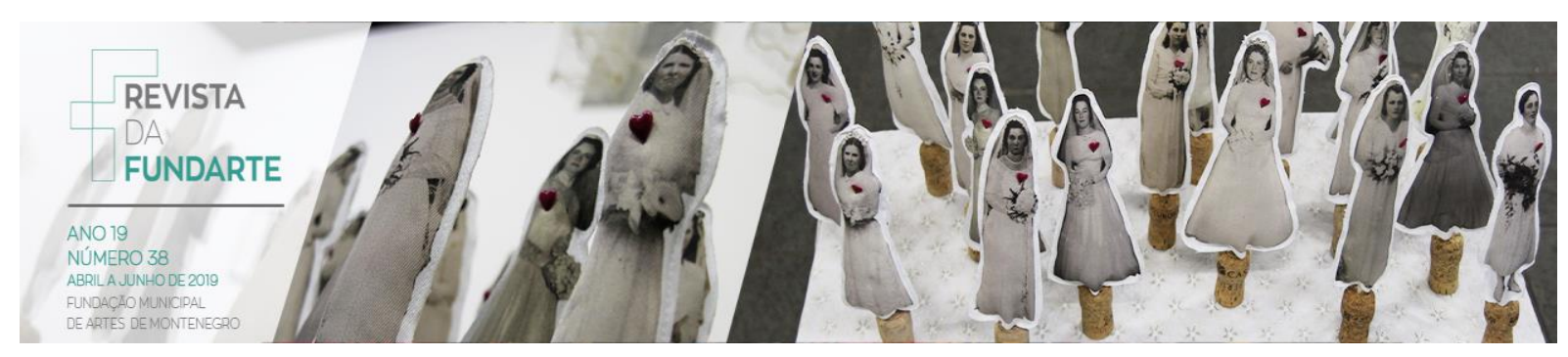

\section{Teoria e Referência}

A articulação final deste estudo incide sobre o questionamento: "Qual a contribuição da produção publicada na RDF para a Educação Musical?". Nesse sentido, o referencial teórico selecionado é constituído com ênfase nas "Dimensões e funções do conhecimento pedagógico-musical" propostos por Kraemer (2000), salutares à compreensão analítica de cada um dos textos sobre música coletados na RDF.

Entende-se que, para o desenvolvimento da Educação Musical, são necessárias apropriações de diferentes conhecimentos, oriundos de estudos realizados nas áreas pertencentes às ciências humanas. Nesse sentido, a apropriação, a transmissão e o desenvolvimento de conhecimentos pedagógicomusicais, como explica Kraemaer (2000), ocorre nos processos relativos as interações pessoal e interpessoal dos sujeitos imbricados nos cenários músicoculturais.

O autor esclarece que a filosofia "procura a essência, o motivo e o sentido de ser e a posição do homem no mundo", e a estética da música, por sua vez, comporta a "reflexão sobre a percepção dos sentidos e conhecimentos", assim como a antropologia pedagógica ocupa-se com as relações estabelecidas entre ambas (KRAEMER, 2000, p. 52).

Os fundamentos da teoria científica - pertinente a este estudo - fortalece 0 surgimento dos questionamentos que norteiam a busca pela compreensão dos textos científicos selecionados e analisados. Conforme Kraemer (2000) corrobora, tais fundamentos polarizam "questões sobre a construção de uma teoria e metodologias científicas" (p. 52), fortalecendo a reflexão sobre a importância da interlocução de saberes entre diferentes fontes geradoras de conhecimentos.

Logo, a história, destinada à ocupação com os fatos ocorridos, contribui à musicologia histórica, que segundo Kraemer (2000), é o "tratamento de fontes musicais, edição histórico-crítica e interpretação de obras musicais, pesquisas biográficas, escrita da história" (p. 54). 


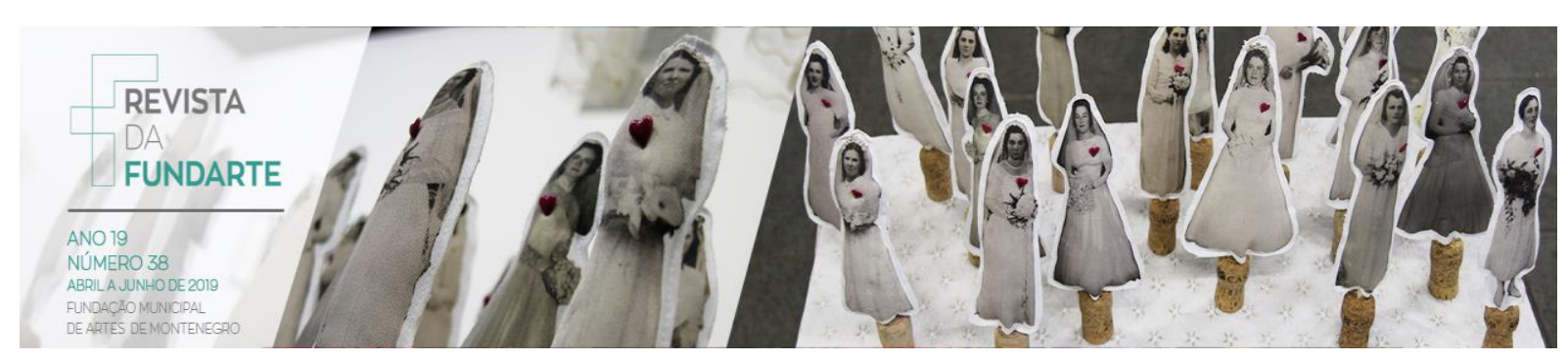

A política e a história de um período, por sua vez, "fornece o modelo de um argumento dominante, uma forma de prática músico-cultural e pedagógica condicionada economicamente" (KRAEMER, 2000, p. 54).

Kraemer (2000) também esclarece que "a psicologia ocupa-se com processos e estados psíquicos, seus contextos, condições e resultados", fato este que contribui à psicologia da música, que se preocupa com a investigação sobre "o comportamento musical e as vivências musicais" (p. 55).

Já a sociologia, "analisa o comportamento de pessoas observando as influências sociais, institucionais e grupos" (KRAEMER, 2000, p. 56), contribuindo assim, à constituição da sociologia da música, que se ocupa destes aspectos relacionando-os à música.

Há, também, outros conhecimentos pertinentes que podem ser transversalizados à música, tais como os destinados às ciências políticas e à pedagogia da arte (KRAEMER, 2000).

A musicologia, segundo Kraemer (2000), “ocupa-se com música, com a variedade de suas formas de manifestação, e analisa as condições do seu surgimento, difusão e compreensão" (p. 58). E a pedagogia, "considera a vida humana sob os aspectos da educação, formação, instrução e didática" (KRAEMER, 2000, p. 59).

Diante do exposto, a música pode estar relacionada a diferentes campos do conhecimento, ligada e interligada à diversas áreas humanas, com o intuito de se compreender a pedagogia da música. Atribui-se, portanto, os conhecimentos pedagógico-musicais a filosofia, a história, a pedagogia, a antropologia, a sociologia, dentre outros que possam subsidiar o seu entendimento e fortalecer, principalmente, o seu campo, enquanto área de conhecimento pedagógico e educativo-musical, ambos pertinentes à esta proposição reflexiva.

\section{Música na Revista da FUNDARTE}

Durante os 18 anos de existência da RDF, muitos foram os assuntos abordados sobre Música, os quais são relacionados e apresentados neste texto. 


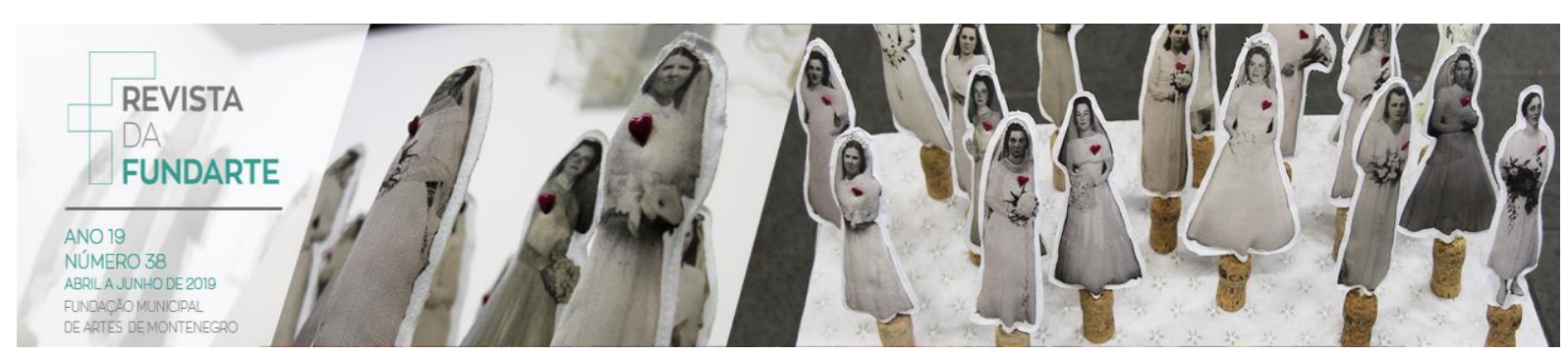

Nesse sentido, as informações são relacionadas a seguir considerando o nome dos autores que publicaram na RDF e o número da edição de cada uma das publicações, as palavras-chave utilizadas, bem como os assuntos abordados de acordo com as áreas da Música consideradas: Composição, Educação Musical, Musicologia, Etnomusicologia, Práticas Interpretativas, além de Interdisciplinaridade, relacionando os textos que apresentam relações transversais às artes.

\section{Quem são os autores da RDF?}

Em considerando o questionamento desta seção, foi possível identificar quem são os autores que compartilham suas pesquisas, ideias e, principalmente, seus saberes com a comunidade científica. Portanto, relacionar seu nome ao número da publicação, bem como ao ano em que esta se encontra vinculada, se tornou salutar para a compreensão da importância da RDF ao contexto artístico-científico. A Tabela 1: Lista de autores e suas publicações, relaciona tais informações, considerando o(s) autor(es) de cada texto publicado.

Tabela 1: Lista de Autores e suas publicações

\begin{tabular}{|c|c|c|}
\hline \multicolumn{3}{|c|}{ LISTA DE AUTORES E SUAS PUBLICAÇÕES } \\
\hline AUTORES & № PUBLICAÇÃO & ANO \\
\hline Adriana Bozzetto & $1 \mid 19$ & $2001 \mid 2010$ \\
\hline Alexandre Birnfeld & 19 & 2010 \\
\hline Ana Claudia Paula do Carmo & 22 & 2011 \\
\hline Ana Denise Ulrich | Sandra Rhoden | Suzana Schöellkopf & 28 & 2014 \\
\hline Ana Lúcia Louro & 31 & 2016 \\
\hline André Müller Reck & 27 & 2014 \\
\hline $\begin{array}{l}\text { Bruno André Antunes | Cristina Cabral Fernandez | Eliana Haas | Felipe } \\
\text { Pereira Claudio | José Luiz Gularte | Sinval Junior | Maria Cecília } \\
\text { Rodrigues Torres }\end{array}$ & 29 & 2015 \\
\hline Bruno Felix da Costa Almeida | Cristiana Rolim Wolffenbüttel & 30 & 2015 \\
\hline Catarina Justus Fischer & $28 \mid 34$ & $2014 \mid 2017$ \\
\hline $\begin{array}{l}\text { Cláudia Bellochio | Caroline Silveira Spanavelli | Eliane da Costa Cunha } \\
\text { | Helena Marques Pimenta }\end{array}$ & 5 & 2003 \\
\hline Cristiane Duarte Sacramento & 15 & 2008 \\
\hline Cristina Mie Ito Cereser & 5 & 2003 \\
\hline Cristina Rolim Wolffenbüttel & $7|9| 11|15| 21 \mid 24$ & $\begin{array}{c}2004|2005| 2006 \mid 2008 \\
2011 \mid 2012 \\
\end{array}$ \\
\hline $\begin{array}{l}\text { Cristina Rolim Wolffenbüttel } \\
\text { Daniele Isabel Ertel }\end{array}$ & 27 & 2014 \\
\hline Daltro Keenam Júnior Morgana Kremer & 35 & 2018 \\
\hline Diego Herencio & 33 & 2017 \\
\hline Diego Luís Faleiro Herencio | Cristina Rolim Wolffenbüttel & 34 & 2017 \\
\hline Douglas Rodrigo Bonfante Weiss & 26 & 2013 \\
\hline
\end{tabular}

ALMEIDA, Bruno Felix da Costa; WOLFFENBÜTTEL, Cristina Rolim. A música na Revista da FUNDARTE: contribuições para o pensamento educativo-musical. Revista da FUNDARTE, Montenegro, p.117-163, ano 19, no 38, abril/junho de 2019.

Disponível em: http://.seer.fundarte.rs.gov.br/index.php/RevistadaFundarte/index> 28 de junho de 2019. 


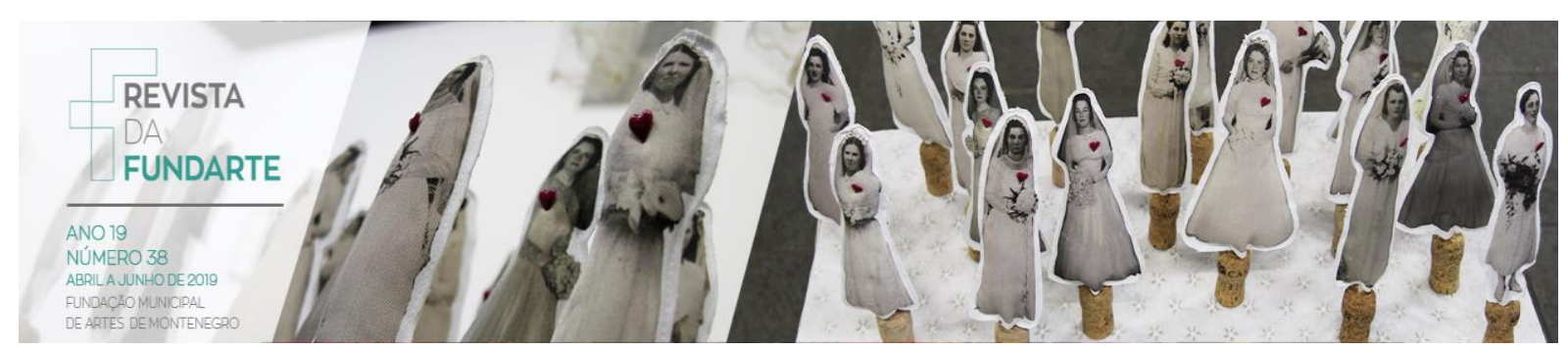

\begin{tabular}{|c|c|c|}
\hline Edgardo Hugo Martinez & 30 & 2015 \\
\hline Eduardo Guedes Pacheco & 30 & 2015 \\
\hline Federico Gariglio & 22 & 2011 \\
\hline Fernanda Anders & 27 & 2014 \\
\hline Fernando Lewis de Mattos & 32 & 2016 \\
\hline Flávio Oliveira & 2 & 2002 \\
\hline Gisele Andrea Flach & 27 & 2014 \\
\hline Greizi Kirst | Leonardo Marques Kussler & 35 & 2018 \\
\hline Helena Dóris Sala | Ana Lúcia Louro & 24 & 2012 \\
\hline Jonas Tarcisio Reis & 20 & 2010 \\
\hline Jorge Zamonner | Graciela Ormezzano & 9 & 2005 \\
\hline José Luiz Martinez & 7 (3 artigos) & 2004 \\
\hline Josemir Valverde & 35 & 2018 \\
\hline Júlia Maria Hummes & $26 \mid 31$ & $2013 \mid 2016$ \\
\hline Júlio Cesar Pires Pereira | Flávia Marchi Nascimento & 26 & 2013 \\
\hline Jusamara Souza & 1 & 2001 \\
\hline Jusamara Souza | Teresa Mateiro | Cláudia Bellochio | Magali Kleber & 5 & 2003 \\
\hline Leda de Albuquerque Maffioletti & 4 & 2002 \\
\hline Leonardo da Silveira Borne | Helena Muciño-Guerra & $31 \mid 34$ & $2016 \mid 2017$ \\
\hline $\begin{array}{l}\text { Lúcia Jacinta da Silva Backes | Cristina Rolim Wolffenbüttel | Ana Maria } \\
\text { Bueno Accorsi }\end{array}$ & 31 & 2016 \\
\hline Luciana Del Ben & 5 & 2003 \\
\hline Luciana Prass & 9 & 2005 \\
\hline Luiz Fernando Cardozo dos Santos & 19 & 2010 \\
\hline Márcia Pessoa Dal Bello & \begin{tabular}{l|l|l|}
10 & 31 \\
\end{tabular} & $2005 \mid 2016$ \\
\hline Márcio Bittencourt Reggiori & 34 & 2017 \\
\hline Marcio Guedes Correa & 32 & 2016 \\
\hline Maria Benincá & 33 & 2017 \\
\hline Maria Cecília de Araújo Rodrigues Torres & $11|17| 22$ & $2006 \mid 2009$ | 2011 \\
\hline Maria Cecília de Araújo Rodrigues Torres | Cláudia Maria Freitas Leal & 26 & 2013 \\
\hline Maria Elizabeth Lucas | Margarete Arroyo | Marília Stein | Luciana Prass & 5 & 2003 \\
\hline Maria Sol Causse & 33 & 2017 \\
\hline Marquessuel Dantas de Souza & 29 & 2015 \\
\hline $\begin{array}{l}\text { Pâmela Göthel Dutra | Cristina Rolim Wolffenbüttel | Ana Maria Bueno } \\
\text { Accorsi }\end{array}$ & 32 & 2016 \\
\hline Patrícia Fernanda Carmem Kebach & \begin{tabular}{l|l|l}
$13-14$ \\
\end{tabular} & $2003 \mid 2007$ \\
\hline Patrícia Fernanda Carmem Kebach | Alexandre Herzog & 26 & 2013 \\
\hline Patrick Aozani Moraes | Sandra Rhoden & 34 & 2017 \\
\hline Paulo Murilo Guerreiro do Amaral & 9 & 2005 \\
\hline Ranielly Boff Scheffer | Cristina Rolim Wolffenbüttel & 29 & 2015 \\
\hline Regiana Blanc Wille & 5 & 2003 \\
\hline Regina Antunes Teixeira dos Santos & $5 \mid 21$ & $2003 \mid 2011$ \\
\hline Rodrigo Sabedot & 36 & 2018 \\
\hline Rosane Cardoso de Araújo & 10 & 2005 \\
\hline Rosangela Duarte | Esther Beyer & 13-14 & 2007 \\
\hline Sandra Rhoden & 23 & 2012 \\
\hline Silvana de Oliveira Gasques | Gabriel Humberto Muñoz Palafox & 24 & 2013 \\
\hline Silvio Ferraz & 29 & 2015 \\
\hline \begin{tabular}{l|l|l} 
Simone de Miranda & Maria Helena Jayme Borges \\
\end{tabular} & 27 & 2014 \\
\hline Simone Nogueira Rasslan | Leda de Albuquerque Maffioletti & 26 & 2013 \\
\hline Sylvia de la Torre | Verónica Pittau & 30 & 2015 \\
\hline Thiago de Campo Kreutz & 27 & 2014 \\
\hline Tiago Oliveira & 30 & 2015 \\
\hline Uirá Kuhlmann & 28 & 2014 \\
\hline Vania Malagutti Fialho & 5 & 2003 \\
\hline $\begin{array}{l}\text { Zuleica Regina Rambo | Bruno Felix da Costa Almeida | Cristina Rolim } \\
\text { Wolffenbüttel }\end{array}$ & 36 & 2018 \\
\hline
\end{tabular}

Nesta relação destacam-se, entre autorias e co-autorias, em se tratando do número de artigos publicados na RDF, as autoras: Cristina Rolim Wolffenbüttel, com doze publicações, e Maria Cecília de Araújo Rodrigues Torres, com cinco

ALMEIDA, Bruno Felix da Costa; WOLFFENBÜTTEL, Cristina Rolim. A música na Revista da FUNDARTE: contribuições para o pensamento educativo-musical. Revista da FUNDARTE, Montenegro, p.117-163, ano 19, oㅜ 38, abril/junho de 2019.

Disponível em: http://.seer.fundarte.rs.gov.br/index.php/RevistadaFundarte/index> 28 de junho de 2019. 


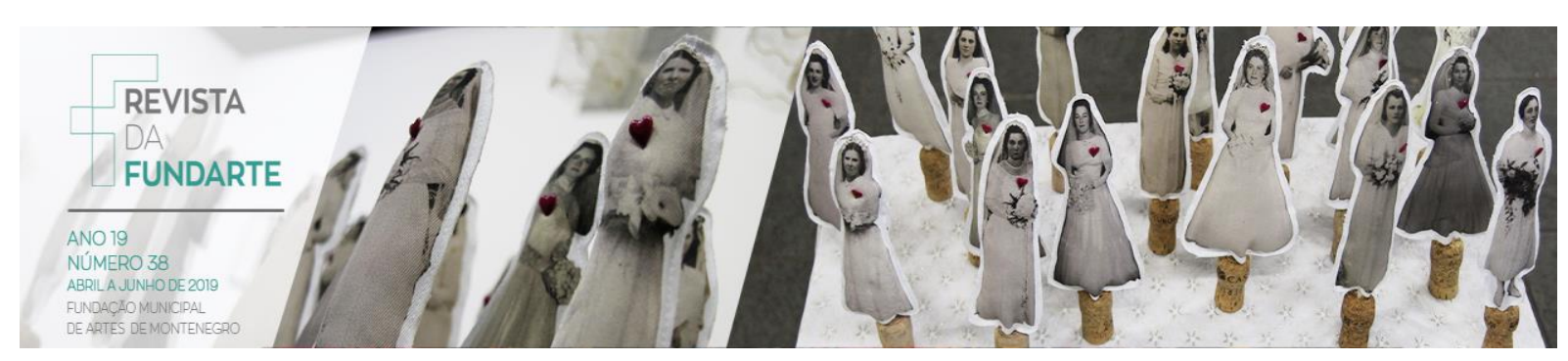

publicações. Além delas, destacam-se, os autores Patrícia Fernanda Carmem Kebach, José Luiz Martinez e Sandra Rhoden, com 3 publicações. E, com duas publicações, os autores Adriana Bozzetto, Bruno Felix da Costa Almeida, Catarina Justus Fischer, Diego Luís Faleiro Herencio, Júlia Maria Hummes, Leonardo da Silveira Borne, Helena Muciño-Guerra, Márcia Pessoa Dal Bello e Regina Antunes Teixeira dos Santos.

\section{Em quais edições da RDF estão presentes os artigos sobre Música?}

Ao decorrer da análise das edições da RDF foram identificados 87 artigos, cujo conteúdo relaciona-se à música. Deste quantitativo, foi possível relacionar a edição número 5 , do ano de 2003, com 9 artigos publicados sobre música, seguida das edições de $n^{\circ} 26$, do ano de 2013, e no 27, do ano de 2014, com 6 artigos publicados.

Com 5 textos sobre música destacam-se as edições de ํㅡ 30 , do ano de 2015, ํo 31, do ano de 2016, e oㅜ 34, do ano de 2017 - salienta-se que neste último número, foram publicados 4 artigos e 1 ensaio. Por sua vez, as edições de $n^{\circ} 7$, do ano de 2004, no 9, do ano de 2005 e no 29, do ano de 2015, tiveram 4 textos publicados, sendo que na edição de ํㅡㄹ 29, foram identificados 3 artigos e 1 ensaio publicados.

Com três artigos publicados são relacionadas as edições de $n^{\circ}$ 22, do ano de 2011, oㅡ 28, do ano de 2014, no 32, do ano de 2016, e oㅡ 35, do ano de 2018. Já com dois artigos publicados foram identificadas as edições de $\mathrm{n}^{\circ}$ 1, do ano de 2001, oㅜ 10, do ano de 2005, № 11, do ano de 2006, números 13 e 14, do ano de 2007, oo 15, do ano de 2008, ํo 19, do ano de 2010, ํo 21, do ano de 2011, № 24, do ano de 2012, números 33 e 34 , do ano de 2017, e a última edição publicada e relacionada nesta análise, a de $n^{\circ} \mathbf{3 6}$, de 2018.

Quanto às edições com apenas um artigo publicado com a temática da música estão as de números 2, 3 e 4, do ano de 2002, no 17, do ano de 2009, ㄲo 20, do ano de 2010, no 23, do ano de 2012, e oㅡ 25, do ano de 2013. 


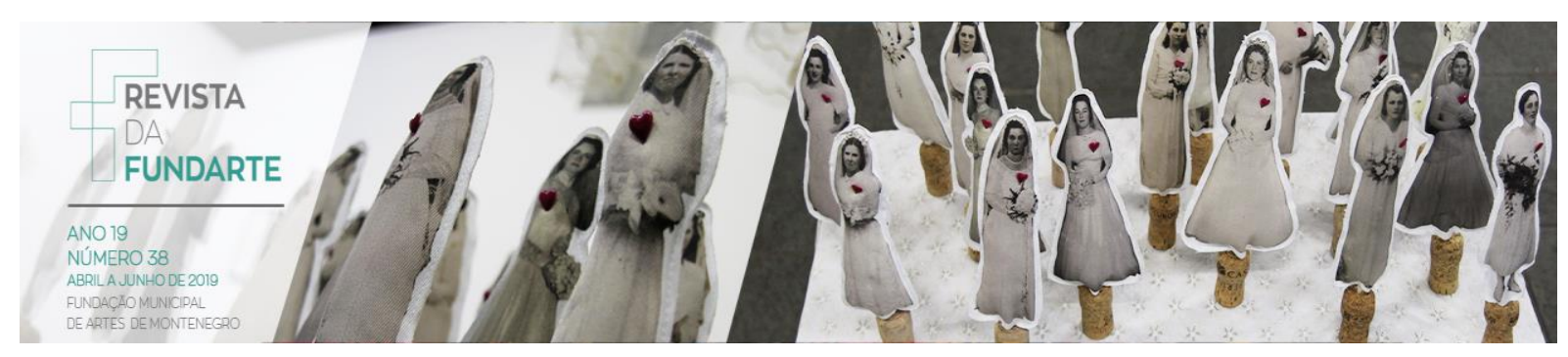

Por fim, dentre as edições analisadas que não foram identificados artigos que remetessem, especificamente, à área da música, quer seja através da leitura dos títulos, resumos e/ou das palavras-chave, são relacionadas a de $n^{\circ} 2$, de 2003, $n=8$, de 2004, nำ16, de 2008, e nำ18, de 2009.

O Quadro 1: Artigo(s) publicado(s) por Número e Ano da RDF, sintetiza estas informações.

\section{O Quadro 1: Artigo(s) publicado(s) por Número e Ano da RDF}

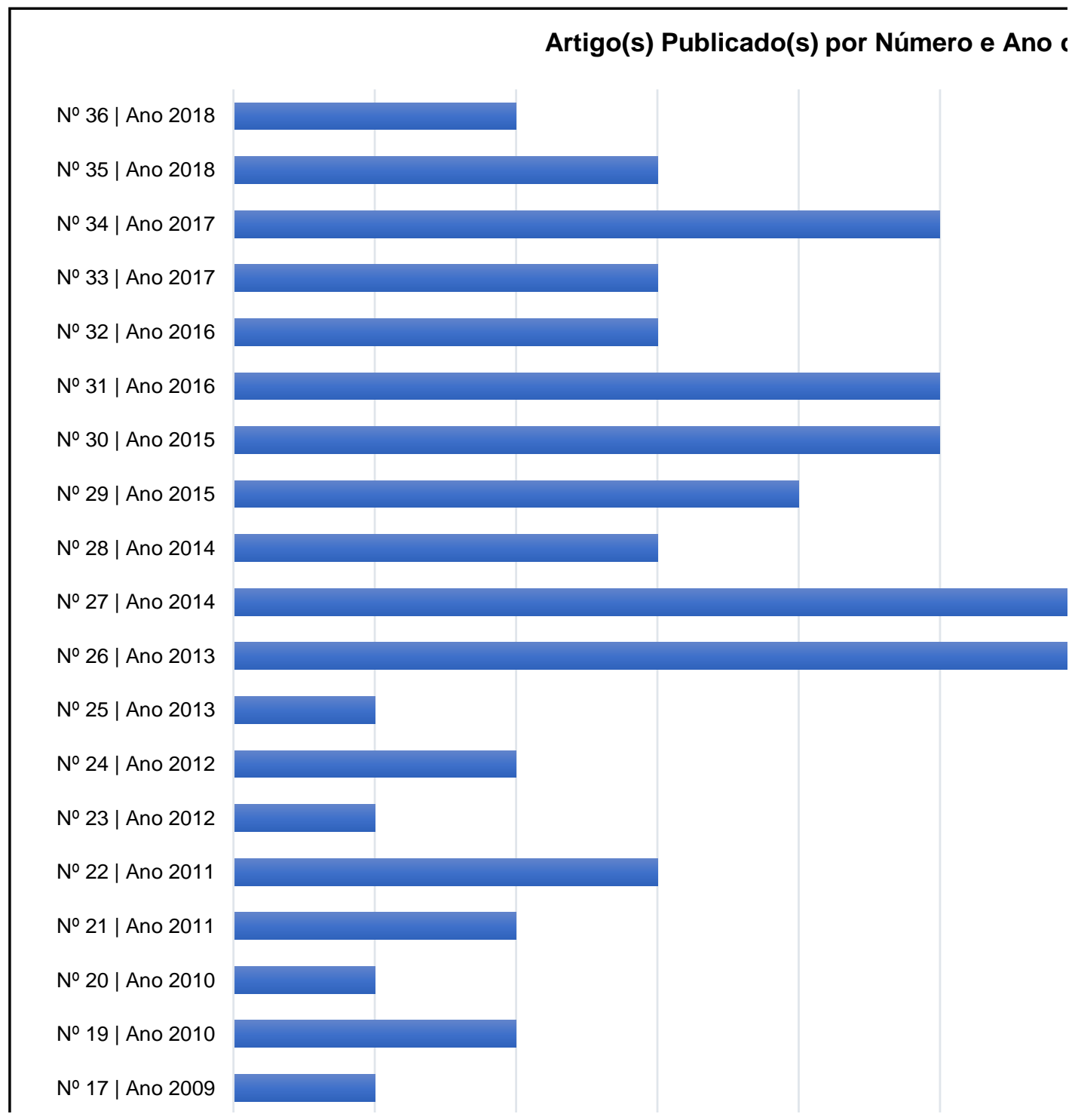

ALMEIDA, Bruno Felix da Costa; WOLFFENBÜTTEL, Cristina Rolim. A música na Revista da FUNDARTE: contribuições para o pensamento educativo-musical. Revista da FUNDARTE, Montenegro, p.117-163, ano 19, ํo 38, abril/junho de 2019.

Disponível em: http://.seer.fundarte.rs.gov.br/index.php/RevistadaFundarte/index $>28$ de junho de 2019. 


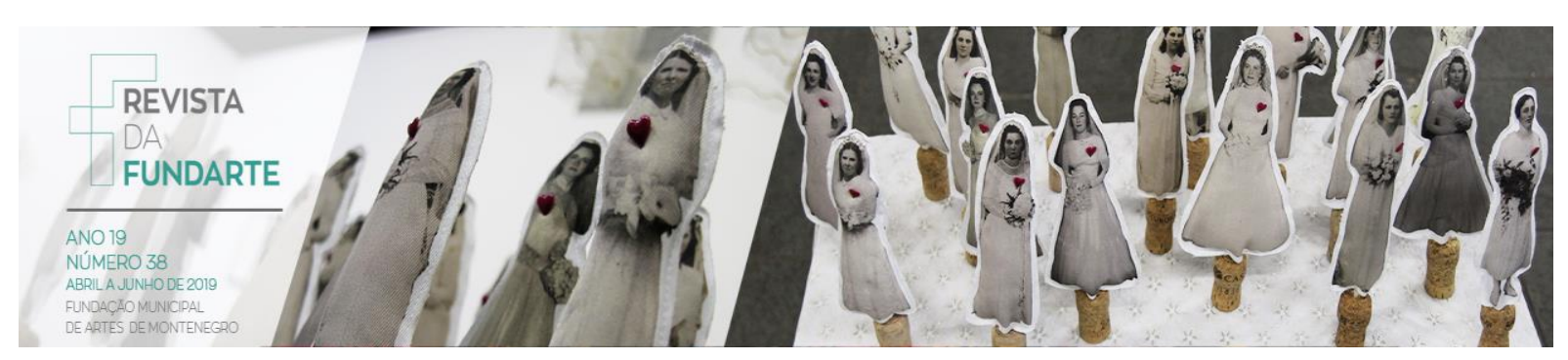

$\underline{\text { Quais as palavras-chave utilizadas? }}$

Dentre as palavras-chave mais utilizadas nos artigos, considerando-se as publicações que possuem artigos com a temática música, com exceção dos três primeiros números da RDF - cujos artigos não possuíam resumos e palavras-chave, e alguns artigos de outras edições que, também, não tiveram esses elementos inseridos pelos seu(s) autor(es) - destaca-se: "Educação Musical”, citada por 28 vezes - incluindo uma menção em língua espanhola, "Educacíon Musical”; "Música”, citada por 12 vezes; e "Educação", citada por 7 vezes.

Além dessas palavras-chave, mesmo que citadas com menor frequência nos artigos analisados, salientam-se as plavras-chave: "Cultura", "Folclore", "Formação de Professores" e "Música na Educação Básica", cada uma citadas por três vezes; e "Cognição", "Criatividade", "Escola Básica", "Estágio Supervisionado", "Ensino de Instrumento", "Etnopedagogia Musical", "Folclore na Escola", "Intersemiose", "Musicalização", "Narrativas de Si", "Pesquisa", "Políticas Públicas" e "Projeto Político-pedagógico", cada uma citada duas vezes.

A Tabela 2: Lista de palavras-chave citadas nos artigos, relaciona todas as palavras-chave citadas e identificadas nos artigos da RDF que assim as possuíam, totalizando 189 palavras.

A Tabela 2: Lista de palavras-chave citadas nos artigos

\begin{tabular}{|lll|}
\hline \multicolumn{1}{|c|}{ LISTA DE PALAVRAS-CHAVE CITADAS NOS ARTIGOS } \\
\hline Abem & Escola de samba & Músicas \\
Acordeom & Escolas de música & Músico \\
Ambiente hospitalar & Espaços de atuação profissional na & Não-formal \\
Análise curricular & educação musical & Narrativas \\
Análise de métodos & Estágio supervisionado & Narrativas de si \\
Análise musical & Estigma & Notação musical \\
Análisis formal & Estudo de levantamento & Paradigmas de pesquisa \\
Aprendizado em música & Etnomusicologia & Pedagogia da música \\
Aprendizagem & Etnopedagogia musical & Pedagogia do piano \\
Apresentações musicais & Evaluacíon docente en música & Percepção musical \\
Arranjo didático & Filosofia da música & Percepção sonora \\
Arte & Final Fantasy & Performance \\
Artes & Folclore & Pesquisa \\
Atividades musicais na escola & Folclore na educação & Pesquisa com crianças \\
Avaliação em música & Folclore na escola & Pesquisa qualitativa e quantitativa \\
Ballet clássico & Formação & Piano em grupo \\
Belém & Formação de professor & Pintura \\
Cognição & Formação de professores & Pluralia tantum \\
Composição musical & Formação de professores de música & Políticas públicas \\
\hline
\end{tabular}

ALMEIDA, Bruno Felix da Costa; WOLFFENBÜTTEL, Cristina Rolim. A música na Revista da FUNDARTE: contribuições para o pensamento educativo-musical. Revista da FUNDARTE, Montenegro, p.117-163, ano 19, no 38, abril/junho de 2019.

Disponível em: http://.seer.fundarte.rs.gov.br/index.php/RevistadaFundarte/index $>28$ de junho de 2019. 


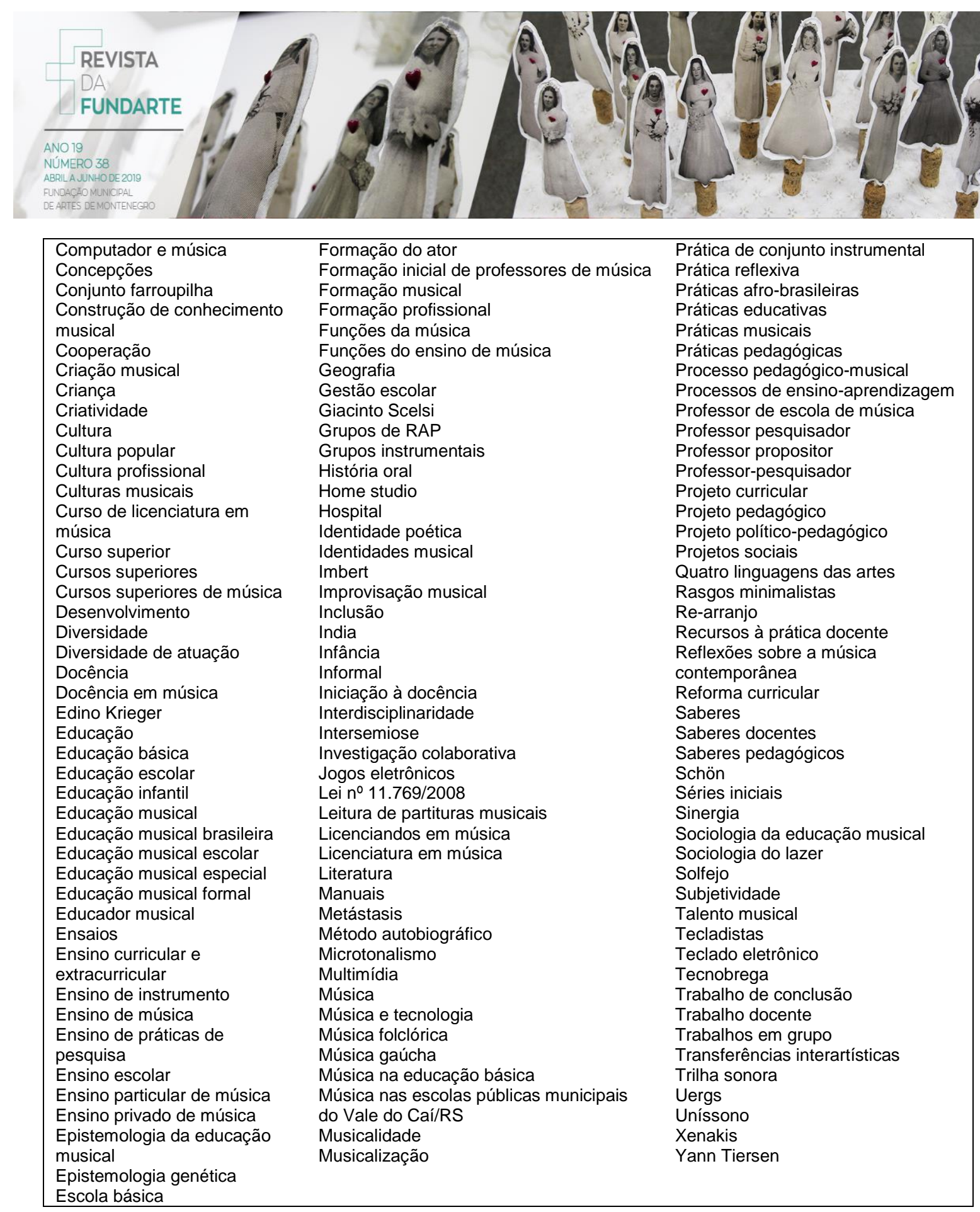

\section{$\underline{\mathrm{O} q u e}$ dizem os artigos?}

Nesta seção são apresentados os principais aspectos de cada um dos textos selecionados, estando organizados de acordo com suas temáticas e considerando a ordem de ano de cada uma das publicações.

ALMEIDA, Bruno Felix da Costa; WOLFFENBÜTTEL, Cristina Rolim. A música na Revista da FUNDARTE: contribuições para o pensamento educativo-musical. Revista da FUNDARTE, Montenegro, p.117-163, ano 19, no 38, abril/junho de 2019.

Disponível em: http://.seer.fundarte.rs.gov.br/index.php/RevistadaFundarte/index> 28 de junho de 2019. 


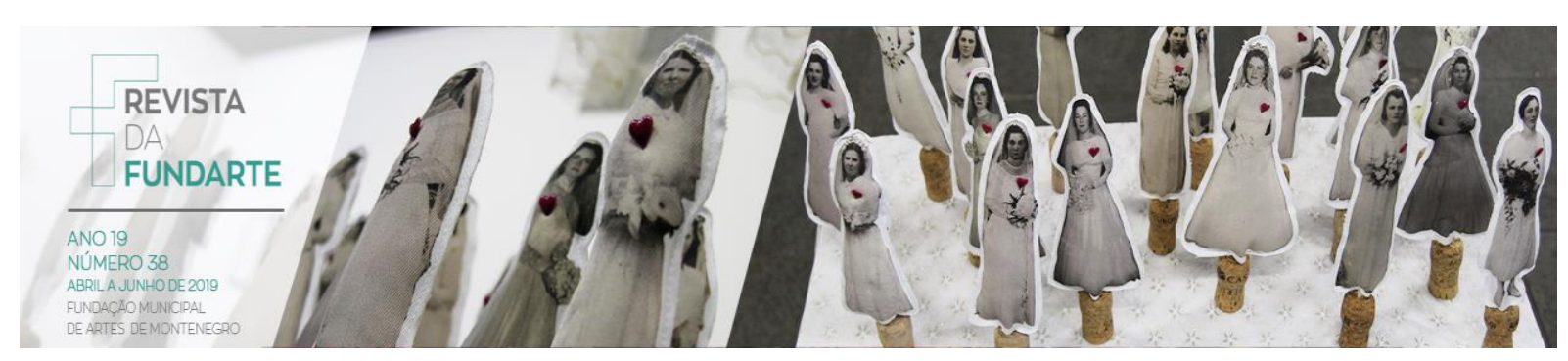

\section{Composição}

Sobre composição musical, foi identificado um artigo que relaciona aspectos da personalidade, das influências, das vivências, dentre outros elementos que podem influenciar o processo criativo de um compositor.

Portanto, o estudo realizado por Valverde (2018) "apresenta uma reflexão sobre a formação da identidade poética de um artista" (p. 53). Para o autor "os posicionamentos filosóficos/intelectuais e as experiências culturais vividas se mostram essenciais para a definição da personalidade artística" (VALVERDE, 2018, p. 63).

\section{Educação Musical}

Em se tratando dos textos relacionados à Educação Musical, foi possível organizá-los de acordo com os diferentes saberes articulados, tais como os relacionados ao campo dos estudos curriculares, da docência em música, da formação docente, das políticas e políticas públicas, da música na educação básica, do ensino especializado de música desenvolvido em diferentes espaços, do ensino de instrumentos musicais, além de estudos relacionados aos processos de ensinoaprendizagem musical e às possibilidades de pesquisas científicas em Educação Musical. Nesse sentido, são apresentados os principais aspectos identificados em cada um dos textos selecionados, considerando as (sub)categorias emergidas.

\section{O Currículo}

Souza (2001), em seu artigo, discute as implicações da diversidade músicocultural para a concepção curricular de música nas escolas. Seu trabalho objetivou analisar as concepções de cultura, a partir das falas de três personagens que participaram de um projeto cultural, que objetivou viabilizar o acesso à música erudita e popular a estudantes de escolas públicas, desenvolvido no Theatro São Pedro, em Porto Alegre/RS. 


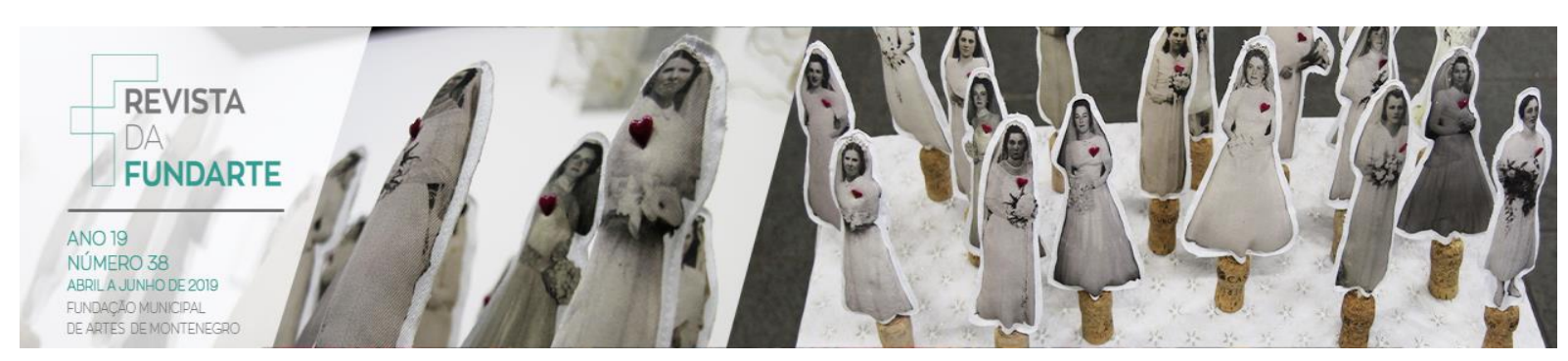

Por outro lado, quanto ao currículo em nível superior, Del Ben (2003) propõese a discutir os processos de reformulação curricular de cursos superiores de música. Para autora, considerar os relatos dos estudantes, bem como a importância dada pelos docentes em repensar as possibilidades de formação do docente em música, consistem em alguns dos aspectos salutares para o contexto curricular destinado à formação deste profissional.

\section{Docência em Música}

A experiência na docência em música é abordada por Bozzetto (2001). Tendo em vista as suas experiências pessoais no cotidiano do ensino de piano, bem como a estreita relação com a literatura especializada no processo de seu ensinoaprendizagem, a autora destaca a importância de o profissional "olhar a sua volta e investir no seu desenvolvimento como profissional da educação" (BOZZETTO, 2001, p. 30).

Nesta mesma perspectiva de estudo, com o intuito de refletir sobre suas experiências como professora de música no ensino básico, Anders (2014) relaciona os significados e as transformações do labor diário na sala de aula. A inclusão da dança e a elaboração de atividades que valorizem o envolvimento dos estudantes nas atividades pedagógico-musicais, são alguns dos aspectos salientados pela autora ao desenvolvimento do ensino musical no contexto investigado.

Por outro, os diferentes campos de atuação do músico, bem como o seu processo formativo, são estudados por Miranda e Borges (2014). Para as autoras, não somente o desenvolvimento experiencial e prático-profissional dos músicos, mas também a ação pedagógica empreendida pelos professores universitários durante a formação profissional destes, são importantes à preparação dos músicos para as diferentes frentes de atuação profissional.

Os saberes docentes, constituídos a partir do cotidiano do ensino de instrumentos musicais de professores bacharéis em música, da Fundação Municipal de Artes de Montenegro - FUNDARTE, concentrou o foco do estudo desenvolvido por Bello (2016). Para a autora, apesar de os cursos de bacharelado em música não 


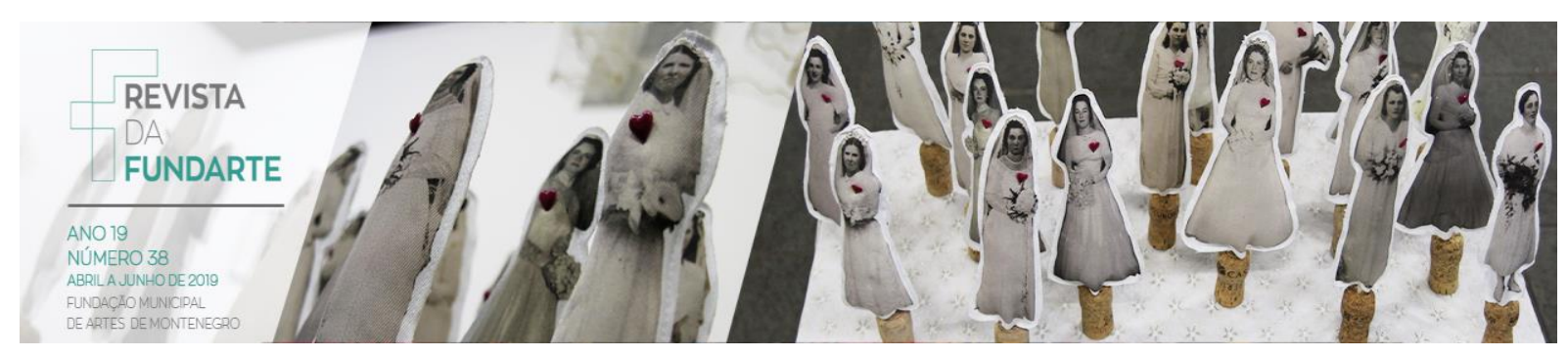

fornecerem conhecimentos sobre o ensino musical, os profissionais formados nesta área buscam, através de formações continuadas, subsídios para seu desenvolvimento profissional.

Sobre a avaliação de docentes em música, Borne (2017) propõe em seu ensaio três eixos norteadores para esta ação, quais sejam: "o que usar, como avaliar e como usar", tornando-os enquanto diretrizes que subsidiam "melhorias no processo de ensino-aprendizagem, e não um instrumento de controle de professores" (p. 203), no intuito de se propor um aprimoramento da ação docente.

\section{Formação Docente}

Ao apresentar sua trajetória de estudos musicais, Oliveira (2001) discorre sobre os aspectos que considera relevante à formação do profissional da música, diante da proposição da "Aula inaugural" do curso de música da Universidade Estadual do Rio Grande do Sul (UERGS). Dentre os aspectos relacionados, o autor salienta a importância de se considerar as funções sociais da música para o desenvolvimento dos estudos musicais.

A formação de professores de música em nível superior também é discutida por Cereser (2003). A autora investigou, a partir das falas de estudantes de licenciatura em música de três universidades federais do Rio Grande do Sul (RS), a relação entre o contexto de formação e suas adequações às práticas pedagógicomusicais. Os resultados apontaram que a formação dos licenciandos investigados estava direcionada à perspectiva acadêmica, necessitando de uma interação mais abrangente entre os componentes curriculares estudados aos ambientes de prática docente.

Por sua vez, Bellochio et al (2003) se propuseram em "investigar a formação, as concepções e as ações em Música de professores não especialistas nesta área" (p. 42). Para as autoras, repensar sobre as possibilidades de acesso ao ensino da música durante a formação inicial de professores do Ensino Fundamental é relevante, considerando-se que a prática musical está presente no cotidiano docente dos profissionais investigados. 


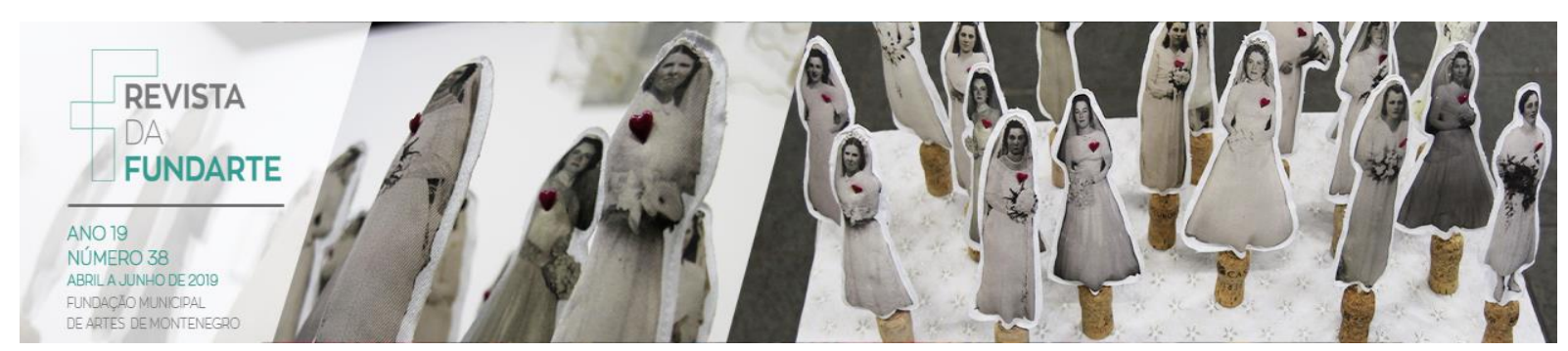

Os saberes pedagógicos dos professores de instrumentos musicais da FUNDARTE foram investigados por Bello (2005). A autora aponta que os saberes pedagógicos desses profissionais, que tiveram sua formação através de cursos de bacharelado em música, os que não contemplaram conhecimentos destinados ao ensino-aprendizado musical, se constituíram na experiência do cotidiano docente, bem como através de cursos destinados ao desenvolvimento do processo de ensino e aprendizado musical, evidenciando assim a preocupação dos professores em construir conhecimentos voltados à docência em música.

A relação avaliativa desenvolvida nos cursos superiores de música e seus impactos à atuação profissional também foi investigada. Nesse sentido, os processos de avaliações de estudantes do curso de licenciatura em música da Universidade Federal do Paraná, nas modalidades de composição, apreciação e execução, foram objetos de estudo de Araújo (2005). A autora constatou, a partir da investigação realizada, a importância de se refletir sobre a condução avaliativa em nível superior considerando as percepções dos licenciandos, à medida que esta relação pode impactar na prática docente dos professores do curso de licenciatura em música.

Balizada pelo questionamento: "Como a música está presente na prática pedagógica do professor de Educação Infantil, de Boa Vista - PR, e quais as concepções de música que norteiam sua ação pedagógica”, Duarte e Beyer (2007) denotaram a importância de possibilitar a valorização e potencialização do pensamento educativo-musical, na busca por teorias que auxiliem na resolução de problemáticas que emergem no cotidiano dos profissionais atuantes na Educação Infantil.

A formação do educador musical para a educação básica foi objeto de investigação de Reis (2010). Os elementos necessários às formação e atuação do professor de música no Brasil são discutidos pelo autor a fim de atingir uma compreensão sobre os recursos educacionais destinados à prática docente desses profissionais. Reis (2010) esclarece que o educador musical organiza e reorganiza a sua práxis a cada desafio cotidiano, se mobilizando à transformação educativa. 


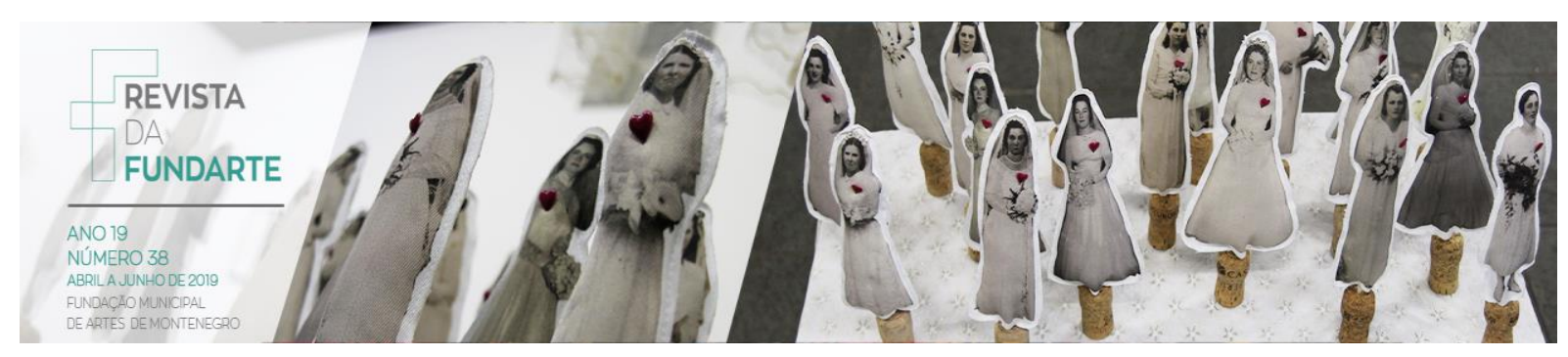

Sobre a integração de tecnologias ao processo de aprendizagem docente, o artigo de Birnfeld (2010) traz algumas considerações sobre a utilização do computador para as funções de escrita, análise e edição musicais, dentre outros recursos em que os estudantes do Curso de Graduação em Música: Licenciatura, da UERGS, puderam se apropriar em busca de seu aprimoramento profissional. Para o autor, as constantes transformações das tecnologias de informática, ao decorrer do tempo, merecem atenção, sendo salutar às transformações e adequações aos métodos de ensino relacionados e para o desenvolvimento profissional.

A observação, o planejamento e a prática musical de bolsistas do Subprojeto Música, do Programa Institucional de Bolsa de Iniciação à Docência (PIBID), nos ensinos fundamental e médio da educação básica, configuraram a síntese das ações de estudantes do curso de licenciatura em música relacionada por Antunes et al (2015). Para os autores, o desenvolvimento docente oportunizado pelo PIBID, contribuiu ao pensamento múltiplo às práticas musicais na escola.

\section{Políticas e Políticas Públicas para a Educação Musical}

Com vistas ao delineamento de novas metas à Educação Musical na região sul do Brasil, Souza et al (2003) refletem, a partir dos assuntos abordados durante a realização da mesa redonda no "VI Encontro Regional da ABEM-Sul", possibilidades para o fortalecimento da Educação Musical. As autoras destacam, dentre outros assuntos, a importância de fomentar o desenvolvimento científico, a formação continuada e a qualificação de debates sobre políticas públicas, junto aos membros da associação.

Gasques e Palafox (2003) analisaram, criticamente, a implementação da Lei Federal ํo 11.769, de 2008, em se tratando de sua representação para os professores atuantes na rede pública-municipal de Uberlândia, Minas Gerais, e para os docentes do curso de formação de músicos da Universidade Federal de Uberlândia, salientando a importância da inserção da música em ambientes escolares. 


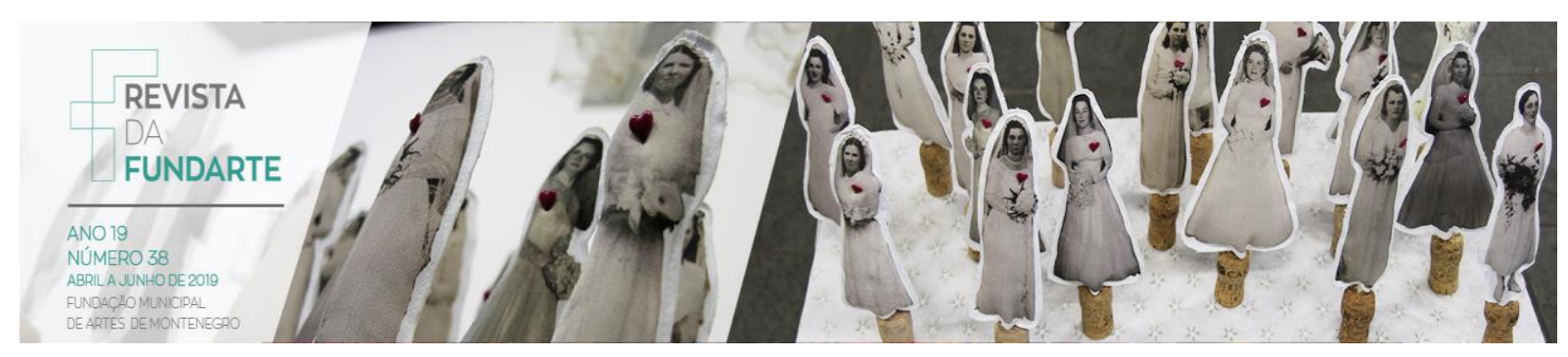

Por sua vez, o ensino musical nas escolas e as concepções da educação musical no Brasil são apresentadas por Wolffenbüttel (2008), a partir da revisão de estudos realizados sobre esta temática. A autora também discute a constituição dos projetos político-pedagógicos, considerando que "a música na educação básica pode ser pensada em uma perspectiva de potencialização do ambiente escolar" (WOLFFENBÜTTEL, 2008, p. 46).

Diante da implementação da Lei ํo 11.769/2008, Hummes (2013) realizou uma reflexão sobre as funções do ensino musical em escolas de Ensino Fundamental e Médio, fundamentada nas categorias de Allan Merriam. Nesse sentido, a autora pondera que "a música está presente no cotidiano das sociedades e exerce várias funções, dependendo da situação em que estiver inserida" (HUMMES, 2013, p. 30), estando, também, presente no cotidiano e nas vivências e experiências dos estudantes.

Sobre o ensino musical em nível superior, Scheffer e Wolffenbüttel (2015) analisaram o projeto pedagógico do curso de Graduação em Música: Licenciatura, da UERGS, à luz da legislação vigente sobre a formulação de cursos de formação docente no Brasil. Para os autores, a formação do "artista/professor", evidenciado na proposta do curso, "caracteriza-se como aquele profissional que transita entre o fazer artístico e docente em ambientes em que a arte é motivo de transformação social" (SCHEFFER; WOLFFENBÜTTEL, 2015, p. 101).

\section{Música na Infância}

A compreensão sobre o processo cognitivo das crianças sobre a estrutura rítmica musical, a partir da epistemologia genética de Jean Piaget, constituiu o objetivo do estudo desenvolvido por Kebach (2003). Para a autora, o desenvolvimento da criança à compreensão sobre a estruturação musical está atrelado, dentre outros aspectos, a faixa etária, o que corrobora a necessidade de o professor de música conhecer "o nível de desenvolvimento de seus alunos para que possa desafiá-los” a outros estágios de conhecimento (KEBACH, 2003, p. 29). 


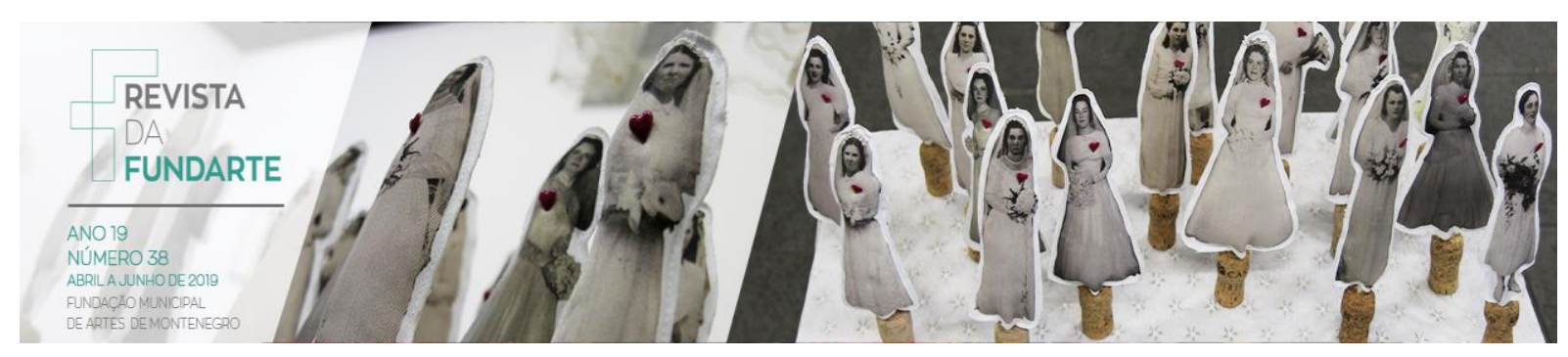

Por sua vez, o brincar e o cantarolar são indispensáveis à aprendizagem infantil. Segundo Carmo e Duarte (2011) é na interação com a cultura, a família, a escola e, principalmente, o contato com atividades que estimulem conhecimentos que as crianças se desenvolvem, pois "sendo a musicalidade uma condição humana, o professor, frente ao ensino da música na escola, pode propiciar às crianças possibilidades de vivenciarem atividades musicais" (p. 22), se conscientizando da importância do ensino da música ao desenvolvimento infantil.

O estudo desenvolvido por Rhoden (2012, p. 44) "teve como objetivo investigar o processo subjetivo da notação musical de um grupo de nove crianças entre 4 a 6 anos, alunos do Curso Básico de Música, da Fundação Municipal de Artes de Montenegro - FUNDARTE". A partir da investigação realizada, a autora esclarece que as crianças revelam, em sua forma de construir a notação musical, os modos de organização de suas narrativas, a partir de sua imaginação e subjetivação.

A educação musical na infância e seus benefícios foram investigados por Rambo, Almeida e Wolffenbüttel (2018). De acordo com os autores, o estudo constatou "que o hábito de cantar com a criança auxilia no desenvolvimento da afetividade, socialização, linguagem e musicalização" (RAMBO; ALMEIDA; WOLFFENBÜTTEL, 2018, p. 26).

\section{Música para Adultos}

Kebach (2007) evidencia a importância de se contemplar atividades de criação musical durante o processo musicalização de adultos. Segundo a autora, o desenvolvimento deste estudo evidenciou que "os processos desencadeados nas tarefas propostas de criação musical preparam e engendram as estruturas de pensamento em relação à formação de esquemas de ação e as compreensões progressivas" do conhecimento musical dos sujeitos observados (KEBACH, 2007, p. 75). 


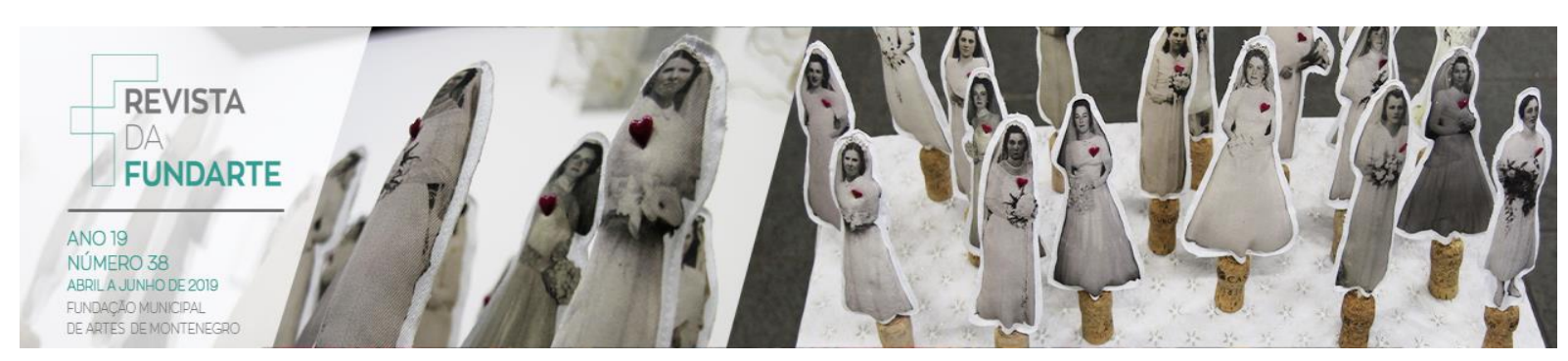

\section{Música na Escola: Ensino e Aprendizagem}

O desenvolvimento da leitura musical, através do solfejo em sala de aula, foi investigado por Santos (2003). Para tanto, foi relacionada a prática reflexiva do solfejo a partir de Davidson e Scripp, considerando os princípios de Schön, o que possibilitou evidenciar as "estratégias técnico-racionais" e o fomento da necessidade do estudante de música à aproximação para com a partitura, identificando questionamentos e problemáticas ao desenvolvimento do conhecimento musical.

Em se tratando de diferentes contextos de aprendizado musical, Wille (2003, p. 48) investigou "como os processos de ensino e aprendizagem musical formal se justapõem às experiências e vivências não-formais e informais dos adolescentes fora da escola". Nesse sentido, a autora salienta a importância da participação de adolescentes em diferentes contextos de aprendizados musicais, viabilizados para além dos espaços formais de educação.

A presença da música na educação básica, a partir da legislação brasileira, foi investigada por Wolffenbüttel (2006). A autora esclarece que a apropriação e a transmissão do conhecimento musical, bem como a prática educativo-musical, encontrada em diferentes espaços, corroboram sobre as concepções educativomusicais em ambientes escolares.

A presença da educação musical no ensino fundamental foi investigada por Sacramento (2008), com objetivo de identificar as atividades musicais realizadas por professores de séries iniciais de escolas públicas municipais de Pelotas - RS. O estudo evidenciou a necessidade de professores especialistas na área para a atuação com ensino da música, apesar de a prática musical ter sido identificada nos contextos investigados.

Wolffenbüttel e Ertel (2014) apresentam o mapeamento realizado nos municípios do Vale do Caí - RS, em se tratando da inserção da música nas escolas municipais da região. As autoras compreenderam que "há um caminho longo a ser trilhado para a efetiva inserção da música nos tempos e espaços das escolas públicas municipais do Vale do Caí, RS" (WOLFFENBÜTTEL; ERTEL, 2014, p. 115), 


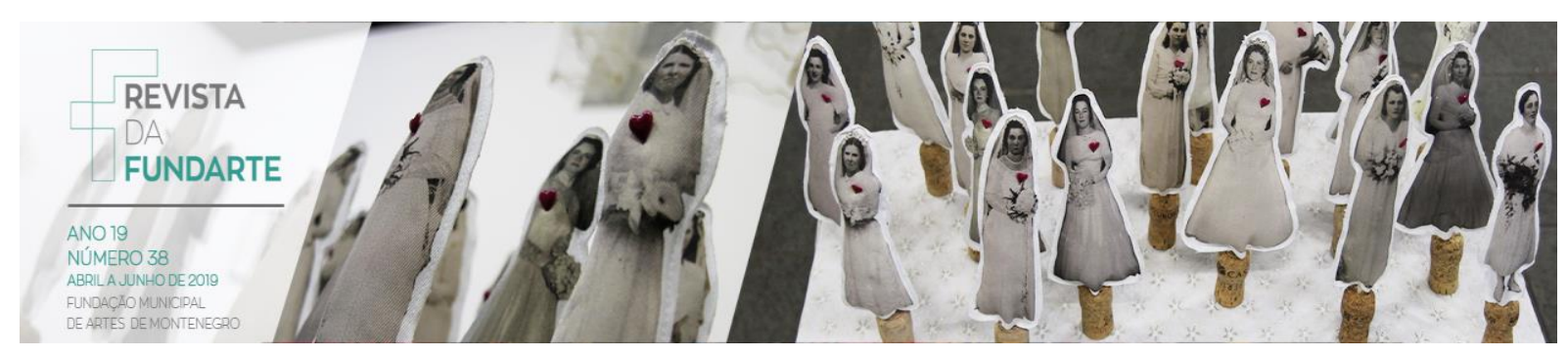

tendo como possibilidade o pensamento de uma política de estado voltada à sua inserção.

Backes, Wolffenbüttel e Accorsi (2015) analisaram as ações pedagógicomusicais presentes no projeto político-pedagógico de escolas municipais, do RS, com ênfase na Lei ํㅜ 11.769/2008. A investigação aconteceu nas turmas do Berçário II e do Primeiro Ano do Ensino Fundamental I, viabilizando a compreensão de que a presença de música esteve articulada, direta e/ou indiretamente, nos ambientes investigados.

Os significados, as influências, as expectativas e o envolvimento de familiares de um grupo de estudantes, participantes do grupo instrumental de uma escola pública municipal de Taquari - RS, foram estudados por Dutra, Wolffenbüttel e Accorsi (2016). De acordo com as autoras, os resultados alcançados puderam subsidiar a reflexão sobre a importância da inserção da música nas escolas, bem como fortalecer políticas públicas que fomentem ações musicais em contexto escolares.

Em se tratando das escolas especializadas no ensino de música, Sabedot (2018) salienta que a educação musical desenvolvida nesses espaços viabiliza "tratar como hipótese que o caráter 'alternativo' e 'livre' das escolas”, salutares à "relação dialógica" ao perfil do corpo docente, podem ser melhores investigadas, ampliando os espaços de atuação do professor de música (SABEDOT, 2018, 41-42).

\section{Música e Instrumentos Musicais: Experiências, Ensino e Aprendizagens}

Em forma de relato de experiência, Torres (2009) discorre sobre a análise do uso de métodos e manuais destinados ao ensino de instrumentos musicais, junto a estudantes do curso de licenciatura em música da FUNDARTE/UERGS. A autora salienta a importância de trocas de experiências e o compartilhamento de informações, propiciados ao grupo de estudantes durante o desenvolvimento das ações pedagógico-musicais.

Santos (2011) reflete, com ênfase na literatura especializada, sobre o ensino de instrumento musical. A concepção do professor-pesquisador emerge no contexto FUNDARTE: contribuições para o pensamento educativo-musical. Revista da FUNDARTE, Montenegro, p.117-163, ano 19, ํo 38, abril/junho de 2019.

Disponível em: http://.seer.fundarte.rs.gov.br/index.php/RevistadaFundarte/index> 28 de junho de 2019. 


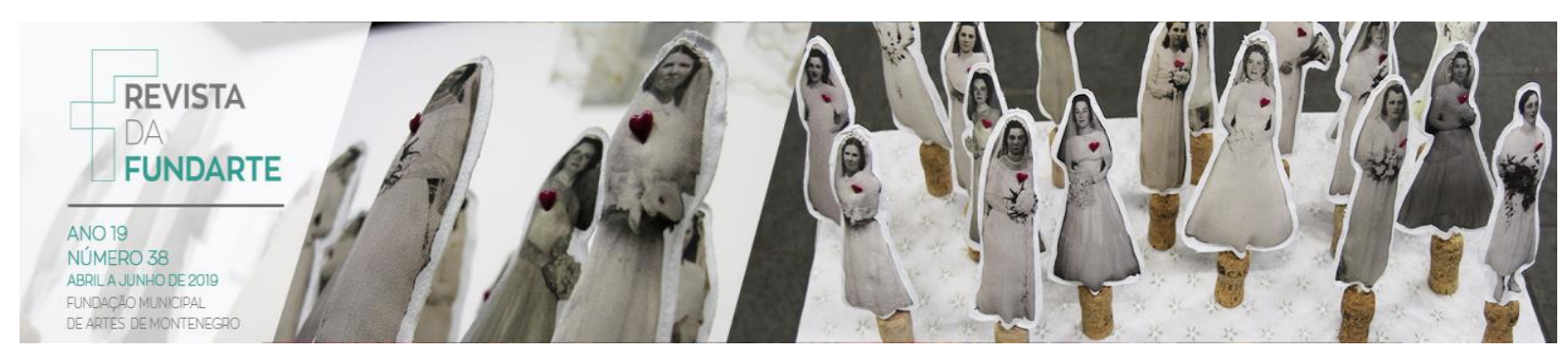

evidenciado pela autora enquanto fomento potencializador da ação docente, além de viabilizar, colaborativamente, o desenvolvimento da área, da ação, e do conhecimento sobre o processo de ensino em música.

Pereira e Nascimento (2013) analisaram métodos para o ensino do acordeom e sua aplicabilidade para o desenvolvimento pedagógico-musical de educadores musicais durante o processo de formação em curso de Licenciatura em Música. Os autores ponderaram que o desenvolvimento de novas metodologias é salutar para a adequação do contexto de aprendizagem do referido instrumento musical.

A formação e a atuação de professores que se dedicam ao ensino de acordeom foi investigado por Weiss e Louro (2013). A partir das narrativas dos docentes, os autores identificaram divergências entre os discursos acadêmico e popular, em se tratando das conexões culturais (popular e erudito), em relação ao estudo do instrumento musical.

A elaboração de arranjos musicais e a didática para a prática e o ensino de piano em grupo foram temas de investigação de Flach (2014). De acordo com a autora, o estudo desenvolvido pode "contribuir para que professores e alunos possam buscar alternativas e ideias para criarem seu próprio material, de acordo com suas necessidades" didático-musicais (FLACH, 2014, p. 31).

Com vistas ao relato da experiência sobre a integração e utilização dos Boomwhackers (tubos percussivos de plástico) em uma proposta pedagógicomusical, junto aos estudantes do sétimo ano da educação básica, Kuhlmann (2014) descreve os procedimentos realizados para a execução da música "Libertango", de Astor Piazzolla. Segundo o autor, o desenvolvimento da atividade proporcionou aos estudantes o compartilhamento e a colaboração no trabalho musical, além de outros aspectos como a criação e o senso estético voltados à música.

$O$ processo de ensino aprendizagem da leitura de partituras musicais foi investigado por Almeida e Wolffenbüttel (2015). Para os autores, o processo de pesquisa-ação desenvolvido junto aos estudantes, participantes das oficinas musicais propostas, possibilitou a compreensão sobre a importância de se adequar as ações de aprendizagem musical às necessidades dos estudantes, em se tratando 


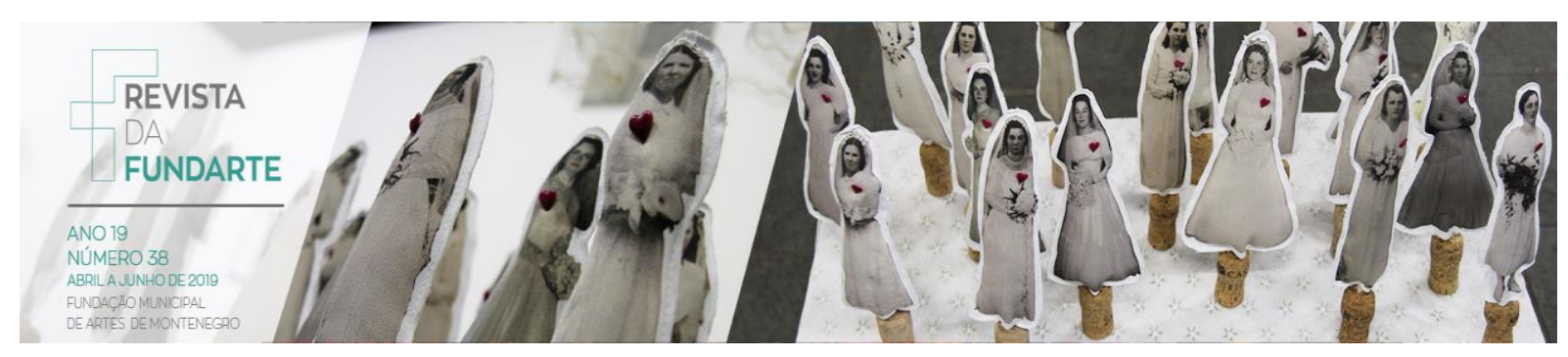

do ensino do instrumento musical teclado e do desenvolvimento de criações musicais com instrumentos musicais alternativos.

A organização do tempo de estudos musicais de estudantes particulares de guitarra elétrica foi o foco de investigação de Oliveira (2015). O autor esclarece que o estudo desenvolvido pode oportunizar reflexões sobre o ensino particular de música, além da compreensão sobre o desenvolvimento do processo de ensinoaprendizagem dos estudantes, por parte dos educadores musicais.

A partir improvisação musical, Hummes (2016) realizou um estudo sobre a cognição musical e a construção do espaço tempo, articuladas em analogias à música para a compreensão da linguagem musical. Considerando como aportes teóricos os estudos de Piaget e Inhelder, a autora constatou que o desenvolvimento de habilidades musicais, por parte da estudante analisada, pode ser desenvolvido entre "acertos e erros" diante dos desafios pedagógicos propostos.

Com o intuito de relacionar dificuldades sobre o ensino e o aprendizado da percepção musical, Fischer (2017), esclarece sobre a importância de se desenvolver estudos sobre esta temática, com o intuito de "otimizar o ensino e o treino dos músicos (cantores, principalmente)" (p. 60), atrelando-o a prática, a escuta, a reprodução, dentre outros aspectos musicais, voltados ao desenvolvimento do estudante de música.

Sobre os caminhos sociais e músico-sociais trilhados por tecladistas em busca de sua formação musical, Benincá (2017) relaciona que o aprendizado e o ensino do teclado eletrônico contemplam, para além de aspectos performáticos, o desafio de se pensar uma educação musical transformadora, criativa e experimental.

A relação do aprendizado musical para com o dom, o talento e/ou hereditariedade, consiste no foco do estudo desenvolvido por Herencio e Wolffenbüttel (2017). Para os autores, cada um dos termos relacionados remetem à uma perspectiva de compreensão educativa, fato este que incide na abrangência e/ou determinação deles, implicando um aprofundamento mais significativo - sendo o intuito do texto iniciar uma discussão sobre esta abordagem. 


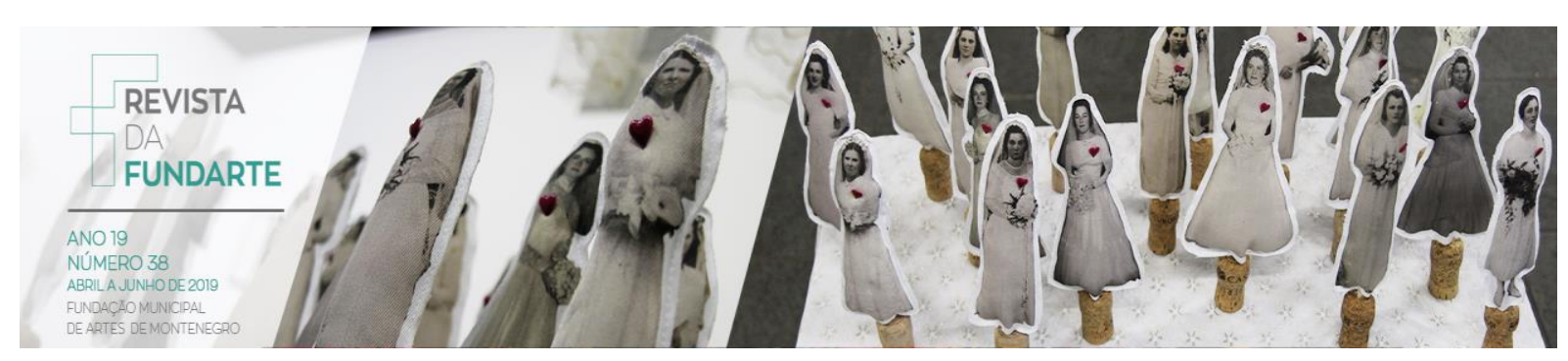

\section{A Educação Musical em Ambientes Hospitalares}

A inserção da música em ambientes hospitalares é o tema abordado por Torres e Leal (2013), que relatam as experiências, como professoras supervisoras do estágio supervisionado dos estudantes de um Curso de Licenciatura em Música, em se tratando da organização, planejamento e a implementação de atividades pedagógico-musicais. O trabalho foi balizado pelo questionamento: "tocar ou cantar para diferentes crianças a cada dia constitui um trabalho de educação musical?" (TORRES; LEAL, 2013, p. 48).

Por sua vez, também sobre a perspectiva de desenvolvimento educativomusical em hospitais, Reggiori (2017) relata em seu texto os principais aspectos da realização de um estágio supervisionado em música em ambiente hospitalar. Segundo o autor, a presença da música nesse ambiente contribuiu para "um momento de humanização pois a música é o único elemento ofertado pelo hospital, no qual pode-se optar por querer ou não", em se tratando da relação com os pacientes e o contexto de ação pedagógico-musical (REGGIORI, 2017, p. 105-106).

\section{$\underline{\text { A Educação Musical e as Necessidades Educativo-musicais Especiais }}$}

O estudo realizado por Borne e Muciño-Guerra (2016) buscou "compreender a experiência e a atuação de professores de música que trabalham com pessoas com deficiência no contexto do México" (p.70). Dentre os aspectos evidenciados pelo estudo, os autores destacaram a falta de oferta de cursos de licenciaturas em música, destinados à formação específica em educação musical especial, e a prática docente como forma de conhecimento específico, para a atuação destes profissionais.

E o acesso ao curso de Licenciatura em Música, por parte de deficientes visuais na UERGS, foi investigado por Keenan Júnior e Kremer (2018). O estudo revelou, dentre outros aspectos, a necessidade de melhorias nas estruturas física e pedagógica da universidade, salutares à um melhor atendimento aos estudantes com deficiência. 


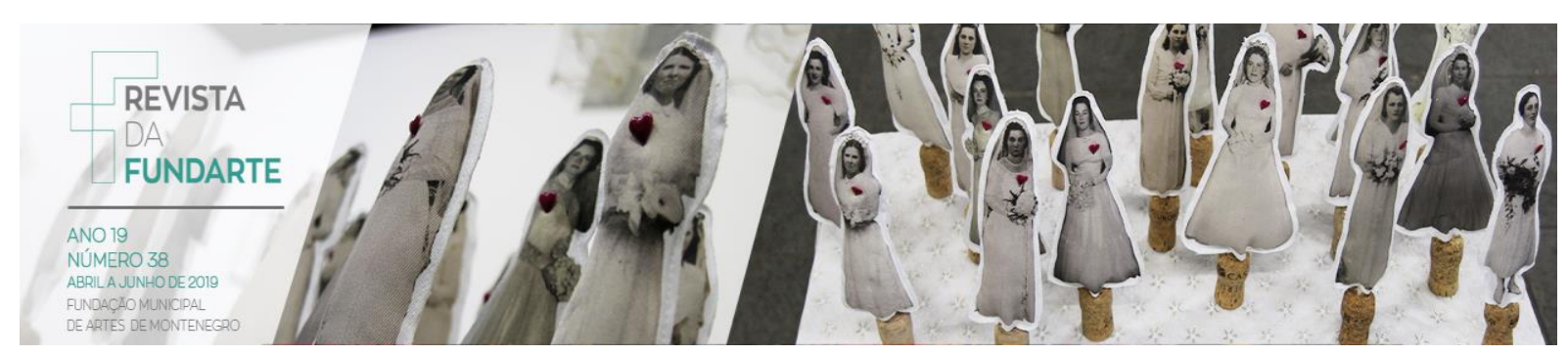

\section{$\underline{\text { Pesquisa em Música }}$}

A escolha de temáticas investigativas dos estudantes do Curso de Graduação em Música: Licenciatura da FUNDARTE/UERGS, configurou o estudo realizado por Torres (2006). A partir de suas vivências, enquanto professora do componente curricular que auxilia os acadêmicos à constituição de suas Monografias de Conclusão de Curso, a autora constatou a diversidade das temáticas selecionadas pelos estudantes, evidenciando, dentre outros aspectos, estudos sobre a trajetória docente e sobre os ambientes de atuação profissional de educadores musicais.

Por sua vez, refletindo sobre o espaço destinado à formação de pesquisadores nos Cursos de Licenciatura em Música e a atuação de professores que se dedicam à esta relação formativa, Torres (2011) relaciona a importância do desenvolvimento da investigação científica em ambientes de nível superior, quer seja através de cursos de graduação, especialização, mestrado e doutorado. Nesse sentido, a ética, os espaços de socialização de projetos e de pesquisas são alguns aspectos salientados pela autora, para o desenvolvimento dos pesquisadores e do fomento de pesquisas.

Em se tratando do campo de estudo da educação, Wolffenbüttel (2011) relaciona os principais assuntos investigados por pesquisadores da área, incluindo o Brasil. Nesse sentido, o campo de estudo, a concepção e a visão educativomusicais, são relacionados pela autora que corrobora a importância de as escolas, os professores, bem como os sistemas de ensino, refletirem sobre o que é e o que compreende o campo de estudo da educação musical em nosso país.

A participação em Recitais Didáticos dos graduandos do curso de licenciatura em Música da Universidade Federal de Santa Maria é tema da investigação realizada por Sala e Louro (2012). A partir dos relatos de experiências dos estudantes, as autoras esclarecem sobre a importância de se realizar pesquisas que problematizem as vivências do cotidiano estudantil, ao passo que estas podem viabilizar contribuições, novas discussões à educação musical, bem como incitar pesquisas na área. 


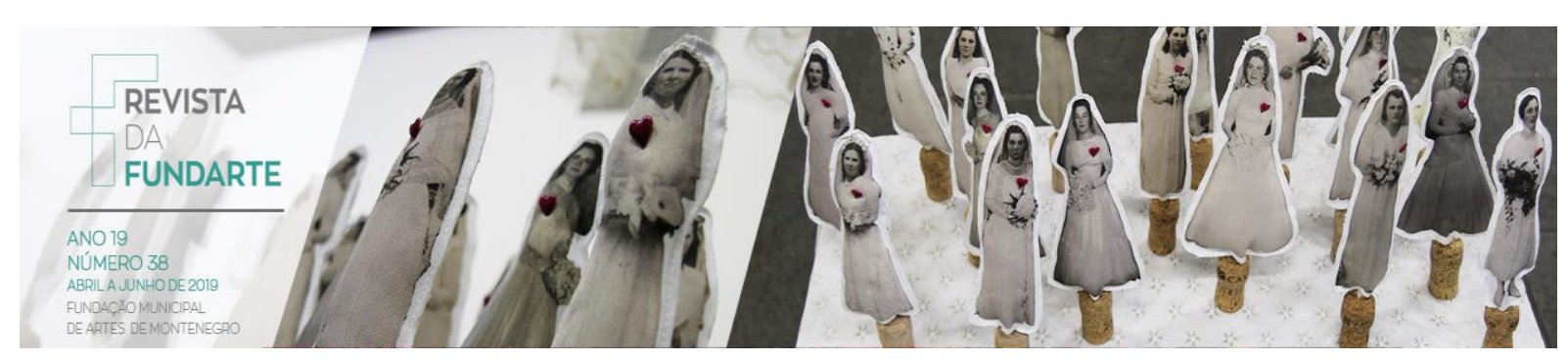

Os paradigmas de pesquisas com abordagens quantitativa e qualitativa, as características que embasam suas propostas e a utilização de ambas as abordagens à constituição e desenvolvimento de investigações em educação musical, são relacionados por Wolffenbüttel (2012). Para a autora, a articulação de temáticas educativo-musicais que sejam subsidiadas pelas referidas abordagens, desde que sejam planejadas adequadamente, "podem contribuir com 0 desenvolvimento da área da educação musical" (WOLFFENBÜTTEL, 2012, p. 37).

Em complementação à esta seção, o desenvolvimento de investigações científicas em música, em se tratando de questões relacionadas às pesquisas (auto)biográficas e a função das narrativas nesse contexto, é tratado por Louro (2016). De acordo com a autora, a utilização desta metodologia investigativa propicia o registro de lembranças sobre os acontecimentos e histórias, no entanto, ainda é pouco explorada na área da educação musical.

\section{Educação Musical e Musicologia}

No entrelaçamento entre as áreas da Educação Musical e da Musicologia destaca-se o estudo sobre a trilha sonora dos dez primeiros episódios da série de jogos Final Fantasy, realizado por Santos e Bozzetto (2010). De acordo com os autores, a análise realizada possibilitou a compreensão evolutiva da música dos jogos eletrônicos, além de viabilizar o conhecimento sobre a "evolução musical nas trilhas sonoras [...], o contexto do compositor e dos recursos tecnológicos que influenciaram suas composições" (SANTOS; BOZZETTO, 2010, p. 45).

\section{Educação Musical e Etnomusicologia}

A cultura popular, a indústria e a produção musical midiática constituem alguns dos temas abordados por Maffioletti (2002). Ao constituir sua crítica-reflexiva sobre a cultura musical no século XX, a autora contextualiza algumas contribuições do "Movimento Hip Hop" e a "Cultura do Karaokê", enquanto meios informais de aprendizado musical. 


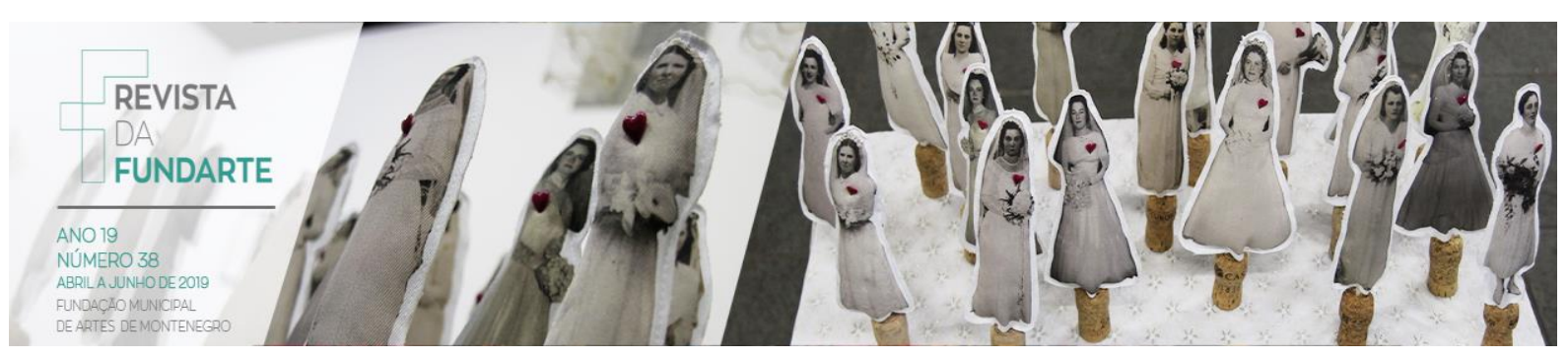

Orientadas pelo método etnográfico-antropológico, o texto de Lucas et al (2003) relaciona os "processos nativos de ensino e aprendizagem musical (etnopedagogias)", considerando o contexto de uma escola de samba, de uma oficina de música e "terno de congo" (p. 4). As autoras refletem que a realização de estudos etnográficos pode contribuir ao fortalecimento da área da Educação Musical, a partir da relação estabelecida entre o aprender e o fazer musical.

As relações estabelecidas entre a aprendizagem e a prática musical extraescolar, bem como suas relações sociais, balizaram o estudo de Fialho (2003), sobre os grupos de Rap de três cidades do RS. Diante das informações coletadas durante o estudo, a autora constatou que as apresentações musicais realizadas pelos grupos de Rap fomentam a prática musical, bem como as formas do fazer e do entender a música neste contexto.

O texto de Wolffenbüttel (2004) relaciona o resultado da pesquisa que "objetivou investigar vivências e concepções de folclore e música folclórica de alunos de 9 a 11 anos do ensino fundamental" (p. 54). Dentre os aspectos observados pela autora, ela constatou a necessidade de planejamento de práticas lúdicas, por parte das escolas, que considerassem as vivências dos estudantes.

Em se tratando dos processos de ensino e aprendizagem musicais em contextos culturais diferentes e das contribuições dos etnomusicólogos que influenciaram o pensamento sobre a música durante os anos 60, Prass (2005) apresenta um panorama das "pesquisas etnográficas sobre etnopedagogias musicais no Brasil” (p. 13). Para a autora, a relação entre essas informações emergidas da etnografia impacta, positivamente, o processo de ensino desenvolvido nas escolas do país.

As relações humano-educativas desenvolvidas dentro do contexto de uma escola de samba de Santa Cataria foram investigadas por Zamonner e Ormezzano (2005). Segundo os autores, foram identificadas três características salutares durante a investigação: os aspectos educativos, as concepções de cultura e arte e as relações subjetivas e intersubjetivas dos membros da escola de samba.

Em busca de uma fundamentação entre o folclore e a educação, Wolffenbüttel (2005) relaciona a concepção conceitual que envolve a interlocução entre as áreas e FUNDARTE: contribuições para o pensamento educativo-musical. Revista da FUNDARTE, Montenegro, p.117-163, ano 19, ํo 38, abril/junho de 2019.

Disponível em: http://.seer.fundarte.rs.gov.br/index.php/RevistadaFundarte/index> 28 de junho de 2019. 


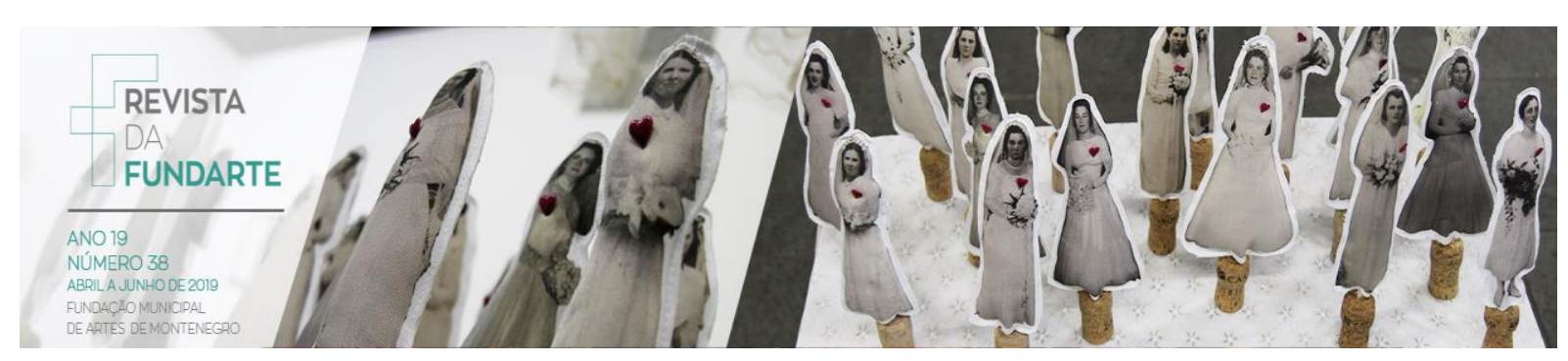

investiga a inclusão do ensino do folclore em ambientes escolares. Nesse sentido, pondera que, em se considerando a "cultura viva e próxima do aluno", nas relações de ensino escolar, "a escola cumpre suas funções de crítica, social e educadora", possibilitando a ressignificação de conhecimentos e saberes sobre folclore (WOLFFENBÜTTEL, 2005, p. 57).

Os projetos sociais em educação musical, na região do Vale do Paranhana, Rio Grande do Sul, foram investigados por Kebach e Herzog (2013). Para os autores, "a musicalização realizada no Vale do Paranhana produz impactos regionais, desde a diminuição da violência em algumas comunidades, segundo relato dos proponentes, até a ampla oferta de expressões artístico-musicais para a região" (KEBACH, HERZOG, 2013, p, 118).

\section{Música e Interdisciplinaridade}

Com interpretações semióticas, Martinez (2004a) trata em seu texto sobre a "música vocal e instrumental, da dança e do teatro como uma unidade multimidiática englobada pelo termo sangita, na Índia" (p. 19). Nesse sentido, as relações de envolvimento, experiência e performance em arte contextualizam, também, sua reflexão sobre a teoria do rasa, remetendo à unidade entre as artes performáticas.

Em a "Rede interdisciplinar de semiótica da música: pesquisa e criação", Martinez (2004b) apresenta o projeto de pesquisa direcionado ao "estudo da intersemiose musical e suas principais manifestações: canção, ópera, música para teatro e dança, música fílmica, música e vídeo, multimídia e hipermídia" (p. 25). autor pondera que a intersemiose é resultante da soma de suas partes em ordem superior, resultante "de formas complexas de signos" (MARTINEZ, 2004b, p. 32).

Com ênfase no pensamento de Charles Peirce e Buckminster Fuller, Martinez (2004c) apresenta "uma teoria geral da intersemiose musical" (p. 33). O autor fundamenta a sua abordagem no estudo do significado da música, a fim de despertar a atenção, em uma diversidade de tempo, de músicos, musicólogos e filósofos. 


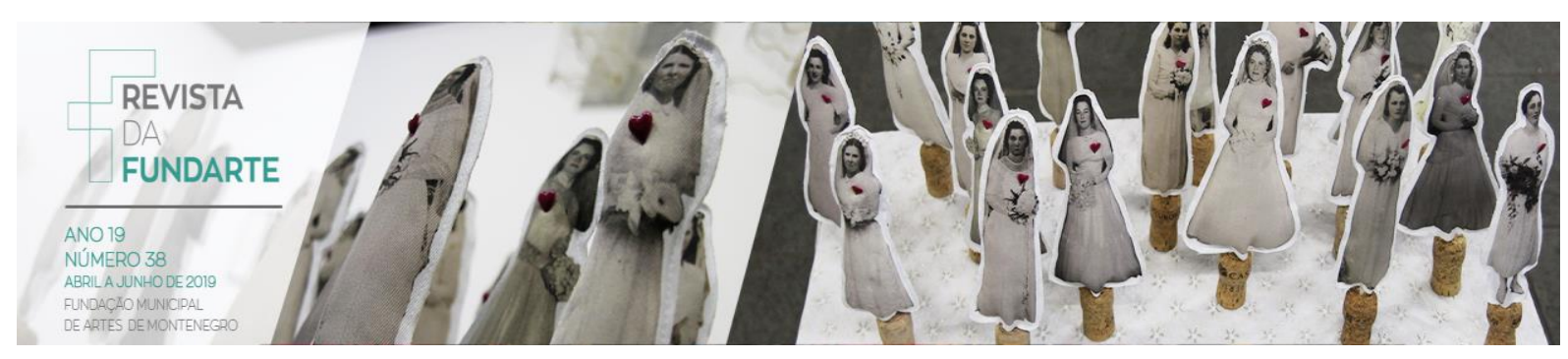

Em uma narrativa autobiográfica, Rasslan e Maffioletti (2013) apresentam uma reflexão sobre a musicalidade inerente ao trabalho do ator, bem como o panorama das investigações já realizadas por pesquisadores brasileiros sobre esta temática. As autoras salientam, dentre outros aspectos, a necessidade da produção científica sobre a presença da música no trabalho do autor e a emergente elaboração de pedagogias musicais destinadas à linguagem teatral.

A utilização da música como facilitadora de seu próprio ensino e de outras disciplinas escolares, e a inclusão de outras disciplinas (história, literatura e outras) para o ensino musical, compreendem a reflexão sobre interdisciplinaridade e música, proposta por Fischer (2014). Para a autora, a interdisciplinaridade pode propiciar e impulsionar o conhecimento a todos, quer seja musical e/ou de outros conhecimentos disciplinares.

A educação contemporânea e o desenvolvimento do "ato criativo" em sala de aula, configuram o tema de reflexão proposto por Ulrich, Rhoden e Schöellkopf (2014), sobre as práticas pedagógicas nas quatro linguagens artísticas (dança, música, artes visuais e teatro). Para as autoras, os olhares, os sentidos (afeto e toque), possibilitam a abrangência do trabalho docente nas linguagens artísticas relacionadas.

Já a literatura, a música, a geografia e a educação configuram a perspectiva de enriquecimento geográfico e a cultura de leitura de mundo, constituem a pesquisa de Souza (2015). Segundo o autor, o estudo preliminar realizado "direciona-se para uma preocupação epistemológica e ontológica do ser-do-homem no geográfico pedagogicamente, bem como apresenta uma preocupação com o lugar do ser-nomundo [...]" (SOUZA, 2015, p. 106).

Ferraz (2015) "propõe um debate conceitual buscando pensar a composição musical dentro de um jogo que articula filosofia, biologia, física, linguística, as tecnologias eletrônicas e digitais" (p. 150). Nesse sentido, para o autor, a música é um modo de comunicação, ligação e articulações sociais entre os povos.

Com o intuito de esclarecer as traduções plásticas e musicais do quarteto de cordas e piano, intitulado "El triunfo de la muerte", de Ezequiel Diz, e inspirada na pintura do artista Otto Dix, Torre e Pittau (2015) esclareceram que a intersecção FUNDARTE: contribuições para o pensamento educativo-musical. Revista da FUNDARTE, Montenegro, p.117-163, ano 19, ํo 38, abril/junho de 2019.

Disponível em: http://.seer.fundarte.rs.gov.br/index.php/RevistadaFundarte/index> 28 de junho de 2019. 


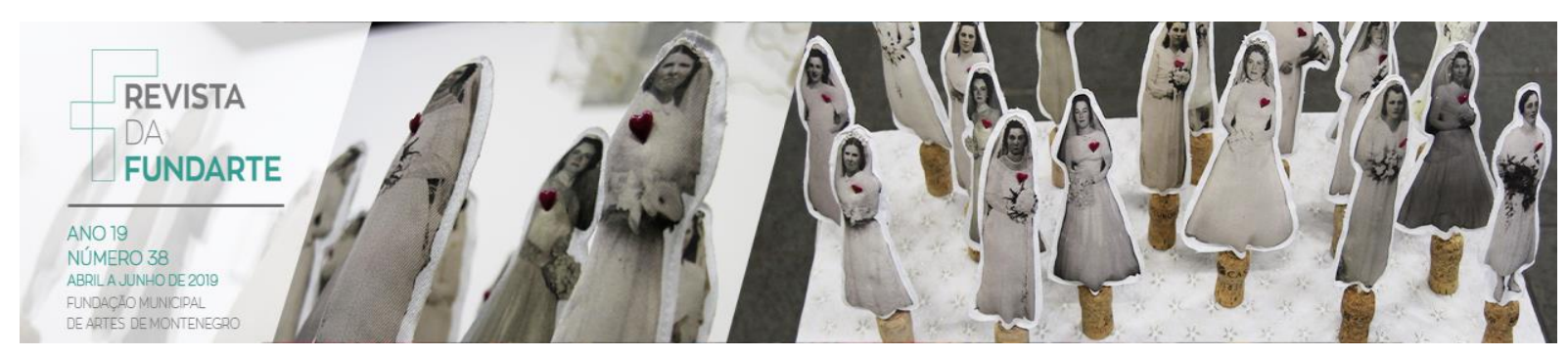

entre as linguagens artísticas viabiliza uma análise semiótica, cuja interlocução enriquece o seu sentido pleno.

Por sua vez, o estudo realizado por Martinez (2015) incide sobre as interações entre música, matemática, geometria e serialismo, presentes em Metástasis (1953-54), de lannis Xenakis, a partir de uma detalhada análise da obra. Deste modo, o autor esclarece que "Xenakis retoma a concepção Pitagórica: os números explicam o universo, e possibilitam uma correlação de identidade entre o mundo físico e o intelectual" (MARTINEZ, 2015, p. 110).

Em se tratando da interlocução entre as áreas da educação e da filosofia (Filosofia da Diferença), Pacheco (2015) propõe problematizar a formação de professores em Artes (artes visuais, dança, música e teatro). Para ele, o docente, nesta perspectiva, "é aquele que tem curiosidade, que deseja entender, estudar, investigar e fazer destas possibilidades elementos de encontro entre outras pessoas", aquele que quer saber sobre "Arte e Educação" (PACHECO, 2015, p. 137).

Com vistas ao aprimoramento da percepção auditiva de estudantes do curso básico de ballet clássico, da FUNDARTE, Moraes e Rhoden (2017) propuseram às alunas, atividades que priorizaram a escuta, bem como a experimentação sonora nas aulas. Segundo os autores, foi possível constatar que, ao decorrer do estudo, as estudantes "conseguiram compreender, identificar e caracterizar os sons presentes no seu cotidiano", além de "estabelecer um diálogo com os movimentos" (MORAES; RHODEN, 2017, p. 92).

\section{Musicologia}

Apresentando as leitura e releitura dos aspectos principais da música de Giacinto Scelsi, Gariglio (2011) denota em seu texto, em abordagem múltipla, a análise estrutural de algumas obras e dos escritos de Tristan Murail, do referido compositor. Além disso, o autor relaciona uma interação entre a perspectiva histórica entre a música de Scelsi e a corrente estruturalista francesa. 


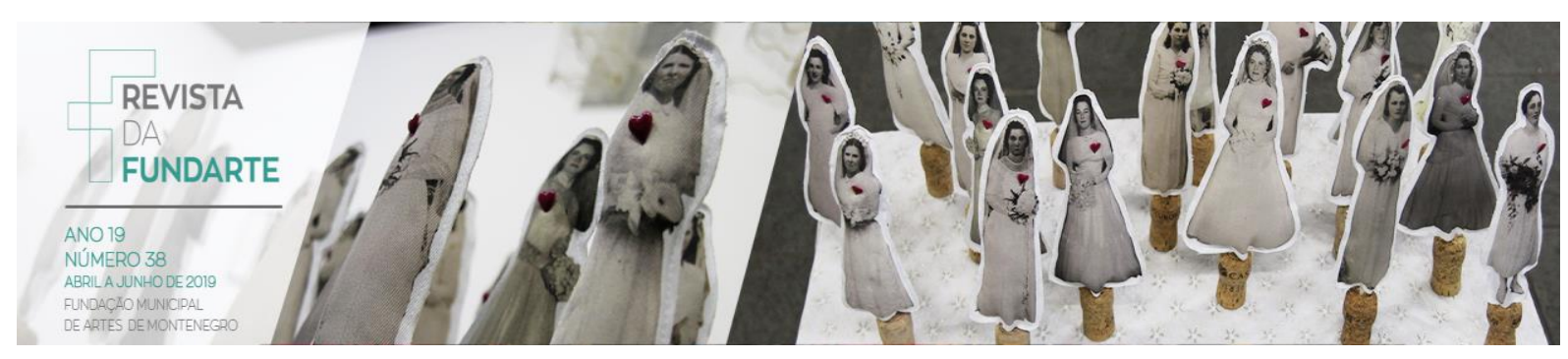

Com ênfase na apresentação, discussão e classificação, realizada por Enrique Imbert (1987), sobre a série de métodos destinados à realização da crítica literária, Kreutz (2014) discute a sua aplicação à análise da Passacalha para Fred Scheiter, de Edino Krieger. Como principais resultados da análise, o autor considera a viabilização de uma visão geral e interdisciplinar da obra e do ciclo de sua comunicação.

O estudo sobre "a polifonia tonal na cifra alfanumérica da música popular" realizado por Correa (2016), relaciona obras de Pixinguinha, Chico Buarque e Tom Jobim. Segundo o autor, as propostas apresentadas apontam "para uma contribuição dos gêneros de música erudita na estruturação do ensino da música popular", além do fortalecimento do estudo de contraponto para a compreensão musical (CORREA, 2016, p. 13).

"Pluraria Tantum: reflexões sobre a música contemporânea" é o título do texto de Mattos (2016), que, em um contexto geral, discute sobre o conservadorismo e os aspectos inerentes à música contemporânea. A reflexão é complementada a partir das acepções, dos referenciais, das atitudes, dos procedimentos, dos valores e dos resultados das acepções da música deste período, elencadas em busca de sua compreensão.

\section{Etnomusicologia}

Entre suas concepções pessoais sobre música e o "tecnobrega" (música eletrônica socializada em Belém do Pará), Amaral (2005) coloca em discussão as potencialidades deste estilo musical, enquanto música de resistência, evidenciando a importância sobre a compreensão do que é ser "brega", ao se dispor à sua escuta diante do contexto cultural investigado.

Em busca da compreensão do caráter multicultural, apresentado na sociedade contemporânea, Reck (2014) realizou um estudo sobre as identidades musicais no contexto musical da cultura gospel. Para o autor: 


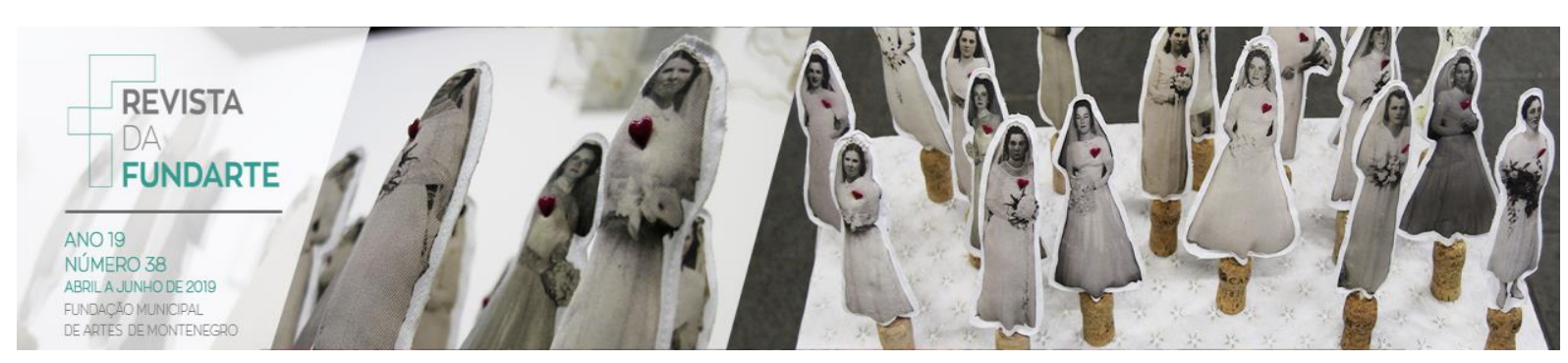

Deixar de ver a identidade musical gospel através do binômio sagrado/profano ou cristão/não-cristão proporciona outros horizontes de análises, ao compreendê-la como uma complexa rede de relações entre as vivências musicais dos adeptos, antes ou depois da conversão; as posições musicais que o sujeito assume em determinadas denominações, dentro das relações sociais; e a partir da regulação que a cultura gospel exerce, principalmente através da mídia e do mercado. (RECK, 2014, p. 162).

\section{$\underline{\text { Paralelos entre Musicologia e Etnomusicologia }}$}

Herencio (2017) investigou a formação e a influência do Conjunto Farroupilha, de Porto Alegre - RS, ao cenário musical gaúcho. Para o autor, compreender a motivação à formação do grupo, bem como relacionar a sua importância para a educação musical, são alguns dos aspectos que podem valorizar o folclore e os mais de 40 anos de existência do conjunto musical no contexto sul-rio-grandense.

A resistência política de artistas e a democracia polarizam a centralidade do texto de Wolkmer (2018). A autora esclarece que "a arte é uma das formas de compreensão de um tempo e sua sociedade, é uma das maneiras pelas quais a cultura se revela, não apenas de forma estética, mas também social" (WOLKMER, 2018, p. 77).

\section{$\underline{\text { Práticas Interpretativas }}$}

"O estilo composicional de Yann Tiersen", é tema da análise musical empreendida por Causse (2017), considerando suas abordagens e diferenças, quanto à corrente minimalista. Segundo a autora, Tiersen é um compositor que imprime em suas obras "combinações de elementos provenientes de diversos gêneros, que o coloca em uma zona de confluência entre o popular, o acadêmico, a música funcional e a eletrônica" (CAUSSE, 2017, p. 185).

\section{Contribuições para o Pensamento Educativo-musical}

A partir da realização do presente estudo, foi possível observar a diversidade de assuntos/temáticas que polarizam a Música enquanto eixo temático, contido nos 


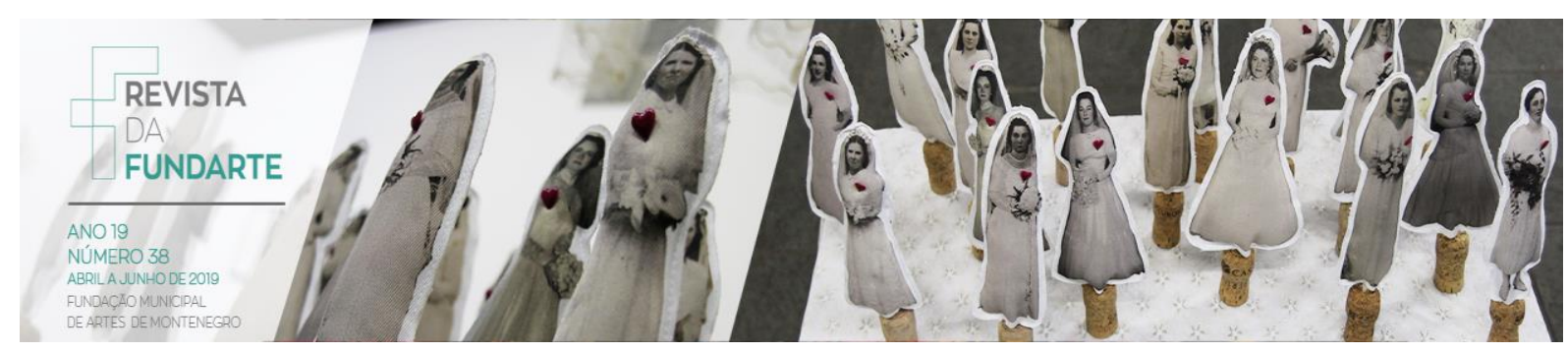

87 textos analisados (artigos e ensaios), dentre as 36 edições da Revista da FUNDARTE. A interlocução reflexiva com os estudos de Kraemer (2000), por sua vez, contribuiu para a relação da Música com as outras áreas do conhecimento, indo além das ciências humanas aos conteúdos que perpassam na interlocução com as ciências exatas, como evidenciado em um dos artigos analisados e relacionados.

A Pedagogia da Música e os assuntos que a permeiam emergem da Educação, da História, da Matemática, da Filosofia, dentre outras áreas, viabilizando a diversidade de conhecimentos à concepção de uma Educação Musical plural em articulação com a Educação, a Pedagogia, a Musicologia, a Etnomusicologia, a Composição e as Práticas Interpretativas.

Nesse sentido, a Música está transversalmente relacionada, interseccionada e integrada às diversas relações sociais psicológicas, humanas e afetivas. Está interligada às áreas da educação, da pedagogia, dentre outras áreas. A histórica e a historicidade também estão presentes nas edições RDF. Essas e outras relações auxiliaram no agrupamento central de ideias, de acordo com as áreas que compartilham com a Música seus conhecimentos e na análise interpretativa dos dados emergidos ao decorrer desta pesquisa.

A Composição musical, enquanto assunto investigativo, está relacionada em um estudo sobre a identidade do sujeito compositor. A Educação Musical, em uma interlocução com áreas afins, polarizou assuntos relacionados ao currículo, ao repertório musical, aos processos de ensino e aprendizagem, aos processos de formação, as políticas e outros assuntos inerentes à música e à educação.

A musicologia e a etnomusicologia, transversalmente presente no periódico em uma articulação com a educação, com a história, com as vivências sociais e psicológicas, remontam e contribuem ao entendimento sobre a música na contemporaneidade. A interdisciplinaridade, ou seja, a relação entre as linguagens artísticas complementa esta gama de conhecimentos que a RDF proporciona ao seu leitor/pesquisador.

Portanto, pensar a pedagogia e a educação musical enquanto um campo que perpassa todos esses conhecimentos evidenciados neste estudo, viabiliza a reflexão 


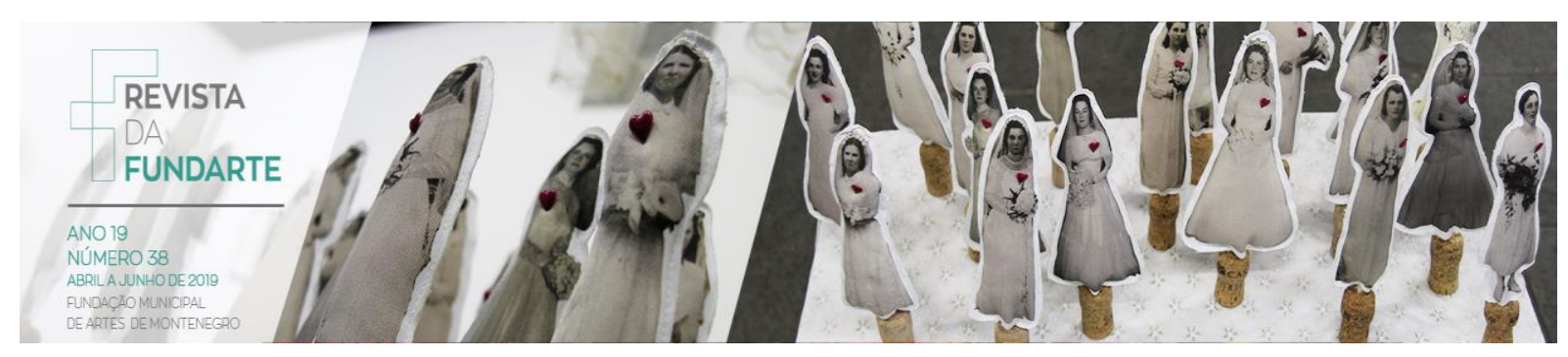

sobre a pluralidade de saberes que a Educação Musical pode abarcar em sua constituição.

Por fim, salienta-se a importância de estudos sobre o "estado da arte" em outros periódicos voltados à educação-arte-música, para o fortalecimento e fomento de conhecimentos e saberes que possam subsidiar o processo educativo-musical na contemporaneidade de forma plural.

\section{Referências:}

ALMEIDA, Bruno Felix da Costa; WOLFFENBÜTTEL, Cristina Rolim. Leitura de partituras musicais: uma pesquisa-ação sobre os processos de ensino e aprendizagem. Revista da Fundarte, Montenegro, ano 15, n. 30, jul./dez. 2015. Disponível em: http://seer.fundarte.rs.gov.br/index.php/RevistadaFundarte/article/view/321/422. Acesso em: 03 dez. 2018.

AMARAL, Paulo Murilo Guerreiro do. O tecnobrega de Belém do Pará, "Entre Tapas e Beijos". Revista da Fundarte, Montenegro, v. 5, n. 9, jan./jul. 2005. Disponível em: http://seer.fundarte.rs.gov.br/index.php/RevistadaFundarte/issue/viewlssue/19/39.

Acesso em: 03 dez. 2018.

ANDERS, Fernanda. Minha trajetória como docente em música no ensino básico: desafios e conquistas. Revista da Fundarte, Montenegro, ano 14, n. 27, jan./jun. 2014.

Disponível em: http://seer.fundarte.rs.gov.br/index.php/RevistadaFundarte/article/view/51/136. Acesso em: 03 dez. 2018.

ANTUNES, Bruno André; FERNANDEZ, Cristina Cabral; HAAS, Eliana; CLAUDIO, Felipe Pereira; GULARTE, José Luiz, JUNIOR, Sinval; TORRES, Maria Cecília Rodrigues. Observações, planejamentos e práticas musicais de um grupo de bolsistas PIBID-Música: entre reflexões e ações na Escola. Revista da Fundarte, Montenegro, ano 15, n. 29, jan./jun. 2015. Disponível em: http://seer.fundarte.rs.gov.br/index.php/RevistadaFundarte/article/view/310/407.

Acesso em: 03 dez. 2018.

AQUINO, Thaís Lobosque. Da perspectiva histórica da epistemologia da educação musical escolar: uma análise sobre os saberes musicais na Revista da ABEM e na OPUS - Revista da ANPPOM. OPUS - Revista da ANPPOM. Opus, v. 23, n. 1, abr., $2017 . \quad$ Disponível em: http://www.anppom.com.br/revista/index.php/opus/article/view/421/414 Acesso em: 13 dez. 2018. 


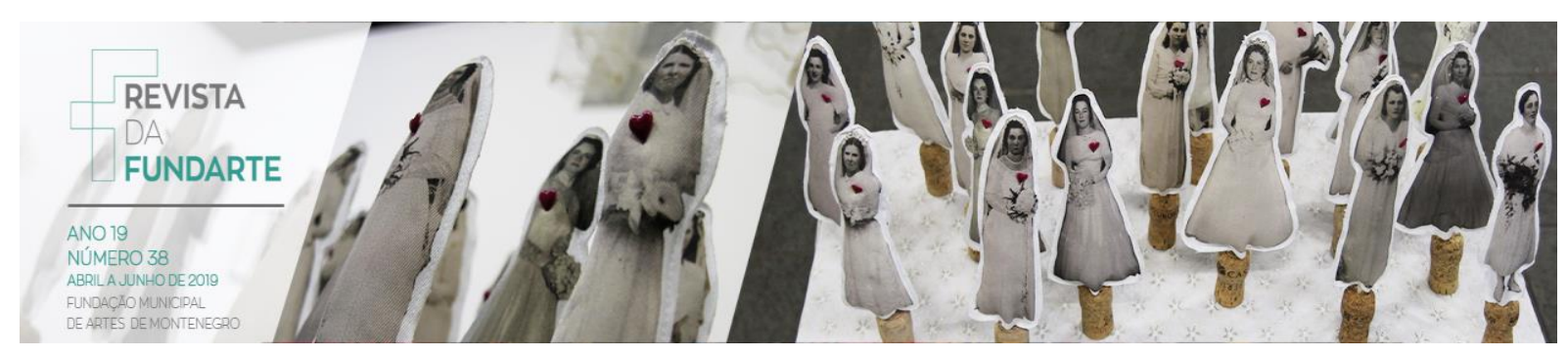

ARAÚJO, Rosane Cardoso de. Um estudo com alunos de licenciatura sobre critérios para a avaliação em música. Revista da Fundarte, Montenegro, ano 5, n. 10, jul./dez. 2005. Disponível em: http://seer.fundarte.rs.gov.br/index.php/RevistadaFundarte/issue/viewlssue/22/42. Acesso em: 03 dez. 2018.

BACKES, Lúcia Jacinta da Silva; WOLFFENBÜTTEL, Cristina Rolim; ACCORSI, Ana Maria Bueno. Práticas pedagógico-musicais na escola em articulação com o projeto político-pedagógico. Revista da Fundarte, Montenegro, ano 16, n. 31, jan./jun. 2016. Disponível http://seer.fundarte.rs.gov.br/index.php/RevistadaFundarte/article/view/331/446. Acesso em: 03 dez. 2018.

BAUER, Martin W.; GASKELL, George; ALLUM, Nicholas C. Qualidade, quantidade e interesses do conhecimento: evitando confusões. In: BAUER, Martin W.; GASKELL, George. Pesquisa qualitativa com texto: imagem e som: um manual prático. 13르 ed. Petrópolis, RJ: Vozes, 2015.

BELLO, Márcia Pessoa Dal. A formação do músico: uma reflexão sobre a docência. Revista da Fundarte, Montenegro, ano 5, n. 10, jul./dez. 2005. Disponível em: http://seer.fundarte.rs.gov.br/index.php/RevistadaFundarte/issue/viewlssue/22/42. Acesso em: 03 dez. 2018.

BELLO, Márcia Pessoa Dal. O bacharel professor de música. Revista da Fundarte, Montenegro, ano 16, n. 31, jan./jun. 2016. Disponível em: http://seer. http://seer.fundarte.rs.gov.br/index.php/RevistadaFundarte/article/view/329/453.

Acesso em: 03 dez. 2018.

BELLOCHIO, Cláudia Ribeiro; SPANAVELLO, Caroline Silveira; CUNHA, Eliane da Costa; PIMENTA, Helena Marques. Pensar em realizar em Educação Musical: desafios do professor dos anos iniciais do Ensino Fundamental I. Revista da Fundarte, Montenegro, v. 3, n. 5, jan./jun. 2003. Disponível em: http://seer.fundarte.rs.gov.br/index.php/RevistadaFundarte/issue/view/13. Acesso em: 03 dez. 2018.

BENINCÁ, Maria. A formação do tecladista de instrumentos eletrônicos: considerações de pesquisa e reflexões. Revista da Fundarte, Montenegro, ano 17, n. 33, jan./jul. 2017. Disponível em: http://seer.fundarte.rs.gov.br/index.php/RevistadaFundarte/article/view/441/547. Acesso em: 03 dez. 2018.

BIRNFELD, Alexandre. Música e tecnologia na UERGS. Revista da Fundarte, Montenegro, ano 10, n. 19, jan./jun. 2010. Disponível em: http://seer.fundarte.rs.gov.br/index.php/RevistadaFundarte/issue/viewlssue/7/7.

Acesso em: 03 dez. 2018. 


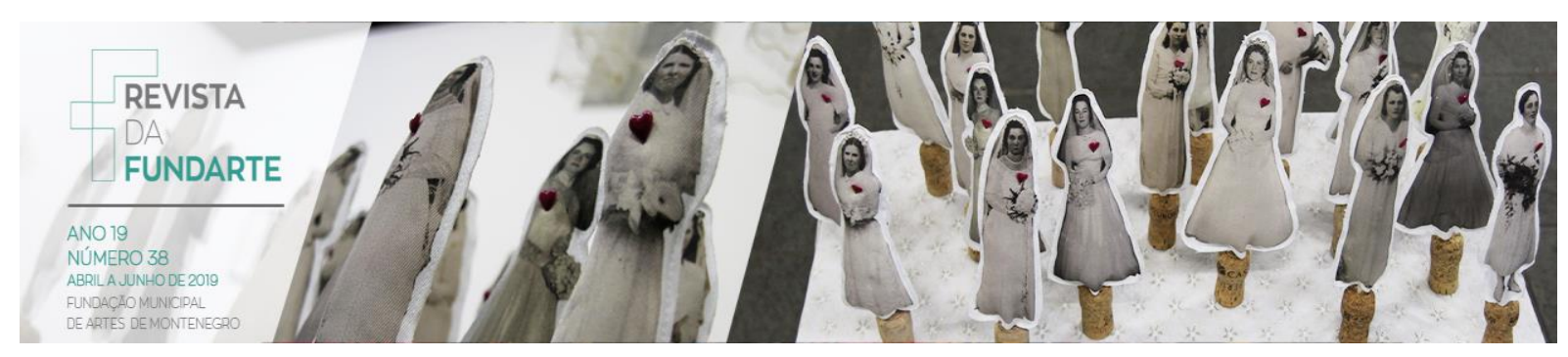

BORNE, Leonardo da Silveira. Consideraciones sobre y para la evaluacíon docente en música. Revista da Fundarte, Montenegro, ano 17, n. 34, ago./dez. 2017. Disponível

http://seer.fundarte.rs.gov.br/index.php/RevistadaFundarte/article/view/451/585.

Acesso em: 03 dez. 2018.

BORNE, Leonardo da Silveira; MUCIÑO-GUERRA, Helena. Actividad y experiencia en educación especial: un estudio en el contexto de México. Revista da Fundarte, Montenegro, ano 16, n. 31, jan./jun. 2016. Disponível em: http://seer.fundarte.rs.gov.br/index.php/RevistadaFundarte/article/view/330/456.

Acesso em: 03 dez. 2018.

BOZZETTO, Adriana. Por um repertório musical tão plural quanto seus intérpretes. Revista da Fundarte, Montenegro, v. 1, n. 1, jan./jun. 2001. Disponível em: http://seer.fundarte.rs.gov.br/index.php/RevistadaFundarte/issue/view/10. Acesso em: 03 dez. 2018.

CARMO, Ana Claudia Paula do; DUARTE, Rosangela. Respeitando as especificidades infantis a partir de práticas pedagógicas que valorizem o ser criança, o brincar, o musicalizar. Revista da Fundarte, Montenegro, ano 11, n. 22, jul./dez. 2011.

Disponível

em:

http://seer.fundarte.rs.gov.br/index.php/RevistadaFundarte/issue/viewlssue/5/5.

Acesso em: 03 dez. 2018.

CAUSSE, Maria Sol. El estilo compositivo de Yann Tiersen: acercamientos y diferencias con la corriente minimalista. Revista da Fundarte, Montenegro, ano 17, n. 33, jan./jul. 2017. Disponível em: http://seer.fundarte.rs.gov.br/index.php/RevistadaFundarte/article/view/449/559. Acesso em: 03 dez. 2018.

CERESER, Cristina Mie Ito. A opinião dos licenciandos em música sobre sua formação. Revista da Fundarte, Montenegro, v. 3, n. 5, jan./jun. 2003. Disponível em: http://seer.fundarte.rs.gov.br/index.php/RevistadaFundarte/issue/view/13. Acesso em: 03 dez. 2018.

CORREA, Marcio Guedes. A polifonia tonal na cifra alfanumérica da música popular: uma proposta analítica fundamentada em três estudos de caso. Revista da Fundarte, Montenegro, ano 16, n. 32, jul./dez. 2016. Disponível em: http://seer. http://seer.fundarte.rs.gov.br/index.php/RevistadaFundarte/article/view/329/453.

Acesso em: 03 dez. 2018.

DEL BEN, Luciana. Situação dos cursos superiores de música no Rio Grande do Sul: relato de uma experiência. Revista da Fundarte, Montenegro, v. 3, n. 5, jan./jun. 2003.

Disponível

em:

http://seer.fundarte.rs.gov.br/index.php/RevistadaFundarte/issue/view/13. Acesso em: 03 dez. 2018. 


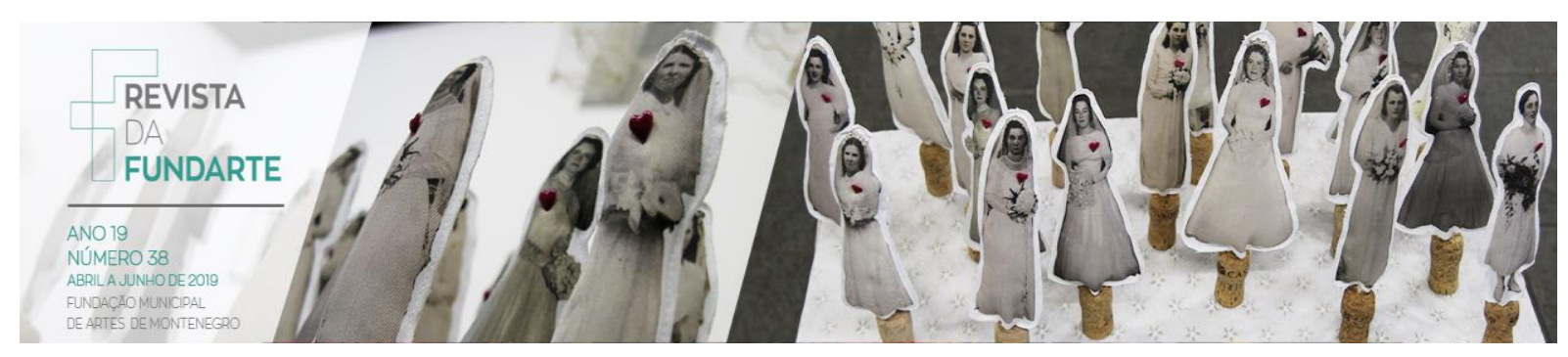

DUARTE, Rosangela; BEYER, Esther. A construção do fazer musical do professor de educação infantil. Revista da Fundarte, Montenegro, ano 7, n. 13 e 14, jan./dez. 2007. Disponível em: http://seer.fundarte.rs.gov.br/index.php/RevistadaFundarte/issue/viewlssue/21/41. Acesso em: 03 dez. 2018.

DUTRA, Pâmela Göthel; WOLFFENBÜTTEL, Cristina Rolim; ACCORSI, Ana Maria Bueno. Estudo sobre a participação de estudantes em um grupo instrumental. Revista da Fundarte, Montenegro, ano 16, n. 32, jul./dez. 2016. Disponível em: http://seer.fundarte.rs.gov.br/index.php/RevistadaFundarte/article/view/429/535.

Acesso em: 03 dez. 2018.

FERREIRA, Norma Sandra de Almeida. As pesquisas denominadas "estado da arte". Revista Educação \& Sociedade, ano XXIII, no 79, ago., 2002. Disponível em: http://www.scielo.br/pdf/es/v23n79/10857.pdf Acesso em: 14 dez. 2018.

FIALHO, Vania Malagutti. Grupos de Rap: seus ensaios e apresentações musicais. Revista da Fundarte, Montenegro, v. 3, n. 5, jan./jun. 2003. Disponível em: http://seer.fundarte.rs.gov.br/index.php/RevistadaFundarte/issue/view/13. Acesso em: 03 dez. 2018.

FISCHER, Catarina Justus. Interdisciplinaridade e a música: reflexões e possibilidades. Revista da Fundarte, Montenegro, ano 14, n. 28, jul./dez. 2014. Disponível http://seer.fundarte.rs.gov.br/index.php/RevistadaFundarte/article/view/149/249. Acesso em: 03 dez. 2018.

FISCHER, Catarina Justus. Percepção musical e vocal: problemas e reflexões. Revista da Fundarte, Montenegro, ano 17, n. 34, ago./dez. 2017. Disponível em: http://seer.fundarte.rs.gov.br/index.php/RevistadaFundarte/article/view/460/575.

Acesso em: 03 dez. 2018.

FLACH, Gisele Andrea. Piano em grupo: arranjos elaborados a partir de alternativas pedagógico-musicais. Revista da Fundarte, Montenegro, ano 14, n. 27, jan./jun. 2014.

Disponível em: http://seer.fundarte.rs.gov.br/index.php/RevistadaFundarte/article/view/49/146. Acesso em: 03 dez. 2018.

GARIGLIO, Federico. El primer uníssono. Revista da Fundarte, Montenegro, ano 11, n. 22, jul./dez. 2011. Disponível em: http://seer.fundarte.rs.gov.br/index.php/RevistadaFundarte/issue/viewlssue/5/5. Acesso em: 03 dez. 2018.

GASQUES, Silvana de Oliveira; PALAFOX, Gabriel Humberto Muñoz. A música como conteúdo obrigatório na educação básica: da lei à realidade escolar [de FUNDARTE: contribuições para o pensamento educativo-musical. Revista da FUNDARTE, Montenegro, p.117-163, ano 19, № 38, abril/junho de 2019.

Disponível em: http://.seer.fundarte.rs.gov.br/index.php/RevistadaFundarte/index> 28 de junho de 2019. 


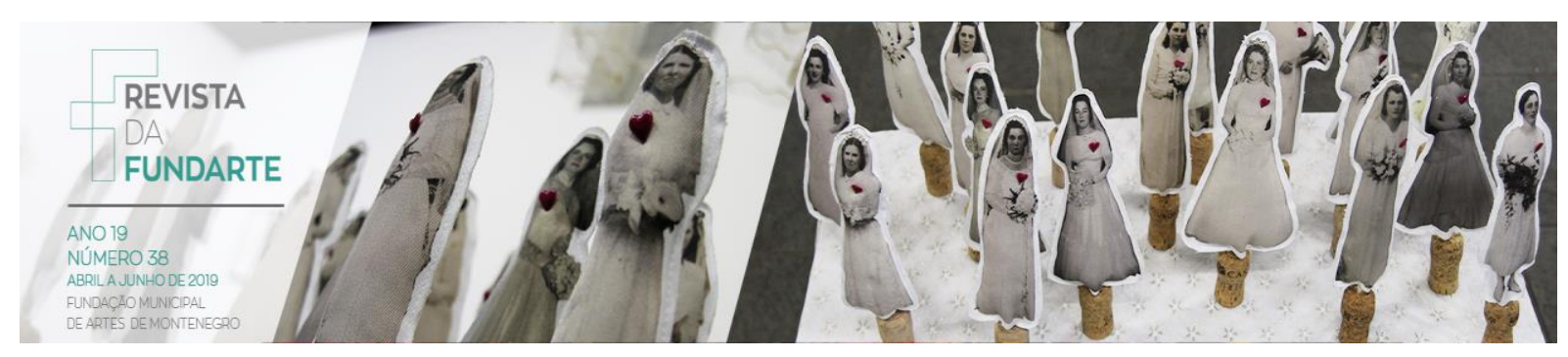

Uberlândia - MG]. Revista da Fundarte, Montenegro, ano 13, n. 25, jan./jun. 2013. Disponível

em:

http://seer.fundarte.rs.gov.br/index.php/RevistadaFundarte/article/view/11/12. Acesso em: 03 dez. 2018.

GILL, Rosalind. Análise de discurso. In: BAUER, Martin W.; GASKELL, George. Pesquisa qualitativa com texto: imagem e som: um manual prático. 13 $3^{\text {a }}$ ed. Petrópolis, RJ: Vozes, 2015.

HERENCIO, Diego Luís Faleiro; WOLFFENBÜTTEL, Cristina Rolim. Aprendizado musical: dom, talento ou hereditariedade? Revista da Fundarte, Montenegro, ano 17, n. 34, ago./dez. 2017. Disponível em: http://seer.fundarte.rs.gov.br/index.php/RevistadaFundarte/article/view/463/581.

Acesso em: 03 dez. 2018.

HERENCIO, Diego. Conjunto Farroupilha: análise histórica e investigação de suas influências para a música do Rio Grande do Sul. Revista da Fundarte, Montenegro, ano 17, n. 33, jan./jul. 2017. Disponível em: http://seer.fundarte.rs.gov.br/index.php/RevistadaFundarte/article/view/439/550.

Acesso em: 03 dez. 2018.

HUMMES, Júlia Maria. A improvisação musical como possibilidade de construção de concepções de tempo e espaço em música. Revista da Fundarte, Montenegro, ano 16, $\mathrm{n}$. 31, jan./jun. 2016. Disponível em: http://seer.fundarte.rs.gov.br/index.php/RevistadaFundarte/article/view/338/451.

Acesso em: 03 dez. 2018.

HUMMES, Júlia Maria. Possibilidades para a música na escola: revisitando as categorias de Allan Merriam. Revista da Fundarte, Montenegro, ano 13, n. 26, jul./dez. 2013.2 Disponível em: http://seer.fundarte.rs.gov.br/index.php/RevistadaFundarte/article/view/15/16. Acesso em: 03 dez. 2018.

KEBACH, Patrícia Fernanda Carmem. A estruturação rítmica musical. Revista da Fundarte, Montenegro, v. 3, n. 5, jan./jun. 2003. Disponível em: http://seer.fundarte.rs.gov.br/index.php/RevistadaFundarte/issue/view/13. Acesso em: 03 dez. 2018.

KEBACH, Patrícia Fernanda Carmem. Invenções musicais em grupo. Uma questão de liberdade de criação, desafio coletivo e cooperação. Revista da Fundarte, Montenegro, ano 7, n. 13 e 14, jan./dez. 2007. Disponível em: http://seer.fundarte.rs.gov.br/index.php/RevistadaFundarte/issue/viewlssue/21/41. Acesso em: 03 dez. 2018.

KEBACH, Patrícia Fernanda Carmem; HERZOG, Alexandre. Musicalização em projetos sociais no vale do Paranhana, Rio Grande do Sul. Revista da Fundarte, 


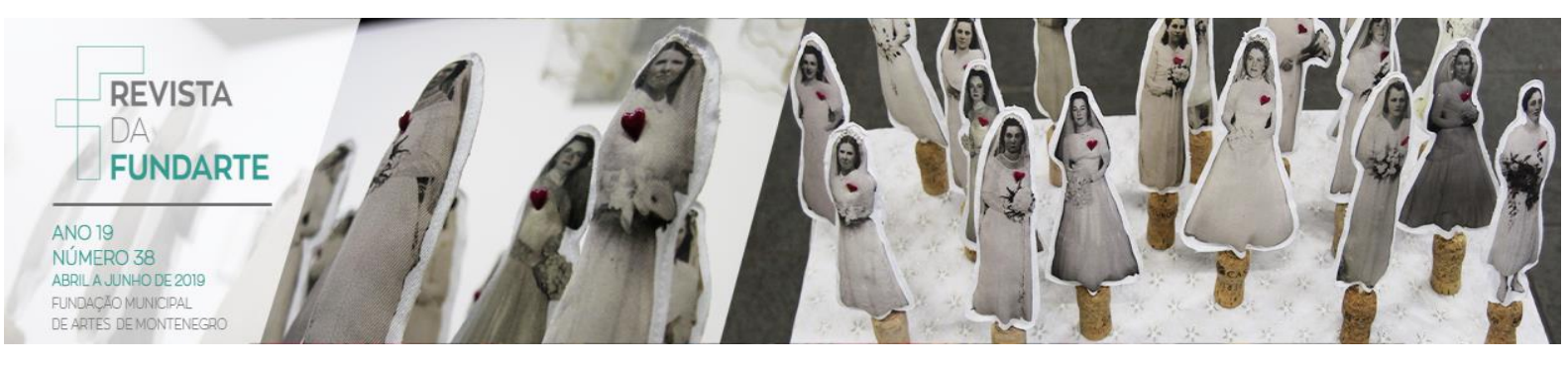

Montenegro, ano 13, n. 26, jul./dez. 2013. Disponível em: http://seer.fundarte.rs.gov.br/index.php/RevistadaFundarte/article/view/21/21. Acesso em: 03 dez. 2018.

KEENAN JÚNIOR, Daltro; KREMER, Morgana. A inserção de estudantes com deficiência visual em cursos de licenciatura em música: um estudo de caso na Universidade Estadual do Rio Grande do Sul. Revista da Fundarte, Montenegro, ano 18, n. 35, jan./jun. 2018. Disponível em: http://seer.fundarte.rs.gov.br/index.php/RevistadaFundarte/article/view/470/603. Acesso em: 03 dez. 2018.

KOCH, Traugott (Apr 1996). "Internet search services". (Translation of a paper given at: "Further on the way to the virtual library! Libraries are using the Internet". Erste INETBIB-Tagung in der UB Dortmund, March 11, 1996.

KRAEMER, Rudolf-Dieter. Dimensões e funções do conhecimento pedagógicomusical. Em Pauta, Porto Alegre, V.11, n. 16/17, abr./nov., p.50-73, 2000. Disponível em: seer.ufrgs.br/EmPauta/article/view/9378. Acesso em: 09 jan. 2019.

KREUTZ, Thiago de Campos. A aplicação dos métodos de crítica literária de Imbert (1987) como ferramenta de análise musical: uma proposta de análise da Passacalha para Fred Schneiter de Edino Krieger. Revista da Fundarte, Montenegro, ano 14, n. 27, jan./jun. 2014. Disponível em: http://seer.fundarte.rs.gov.br/index.php/RevistadaFundarte/article/view/53/138.

Acesso em: 03 dez. 2018.

KUHLMANN, Uirá. Música para tubos voadores: uma experiência com "Libertango" de Astor Piazzolla. Revista da Fundarte, Montenegro, ano 14, n. 28, jul./dez. 2014. Disponível em: http://seer.fundarte.rs.gov.br/index.php/RevistadaFundarte/article/view/154/243.

Acesso em: 03 dez. 2018.

LOURO, Ana Lúcia. Repertórios musicais, práticas pedagógicas e temas de pesquisa: reflexões sobre ensino de pesquisa e música dentro de uma abordagem (auto)biográfica. Revista da Fundarte, Montenegro, ano 16, n. 31, jan./jun. 2016. Disponível em: http://seer.fundarte.rs.gov.br/index.php/RevistadaFundarte/article/view/323/428. Acesso em: 03 dez. 2018.

LUCAS, Maria Elizabeth; ARROYO, Margarete; STEIN, Marília; PRASS, Luciana. Entre congueiros e sambistas: etnopedagogias musicais em contextos populares de tradição afro-brasileira. Revista da Fundarte, Montenegro, v. 3, n. 5, jan./jun. 2003. Disponível em: http://seer.fundarte.rs.gov.br/index.php/RevistadaFundarte/issue/view/13. Acesso em: 03 dez. 2018. 


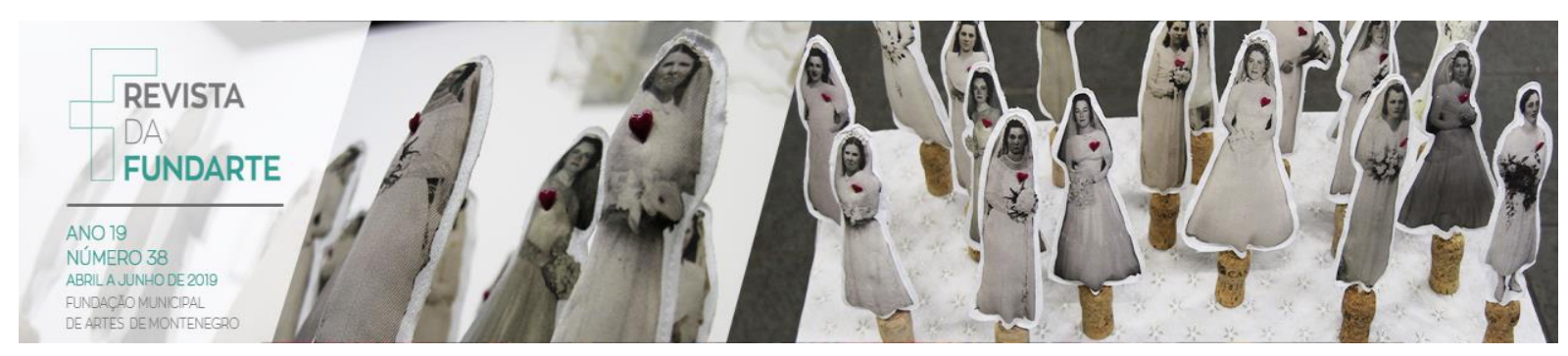

MAFFIOLETTI, Leda de A. Produção musical: o outro lado da diversidade. Revista da Fundarte, Montenegro, v. 2, n. 4, jul./dez. 2002. Disponível em: http://seer.fundarte.rs.gov.br/index.php/RevistadaFundarte/issue/view/12. Acesso em: 03 dez. 2018.

MARTINEZ, Edgar Hugo. Metástasi de Xenakis: uma triangulación entre matemáticas, geometría y serialismo. Revista da Fundarte, Montenegro, ano 15, n. 30, jul./dez. 2015. Disponível em: http://seer.fundarte.rs.gov.br/index.php/RevistadaFundarte/article/view/317/426.

Acesso em: 03 dez. 2018.

MARTINEZ, José Luiz. Sangita: música, dança, teatro e poesia na Índia clássica. Revista da Fundarte, Montenegro, v. 4, n. 7, jan./jun. 2004a. Disponível em: http://seer.fundarte.rs.gov.br/index.php/RevistadaFundarte/issue/viewlssue/16/36.

Acesso em: 03 dez. 2018.

MARTINEZ, José Luiz. A rede interdisciplinar de semiótica da música: pesquisa e criação. Revista da Fundarte, Montenegro, v. 4, n. 7, jan./jun. 2004b. Disponível em: http://seer.fundarte.rs.gov.br/index.php/RevistadaFundarte/issue/viewlssue/16/36.

Acesso em: 03 dez. 2018.

MARTINEZ, José Luiz. Música, semiótica e multimidialidade. Revista da Fundarte, Montenegro, v. 4, n. 7, jan./jun. 2004c. Disponível em: http://seer.fundarte.rs.gov.br/index.php/RevistadaFundarte/issue/viewlssue/16/36.

Acesso em: 03 dez. 2018.

MATTOS, Fernando Lewis. Pluralia Tantum: reflexões sobre a música contemporânea. Revista da Fundarte, Montenegro, ano 16, n. 32, jul./dez. 2016. Disponível em: http://seer.fundarte.rs.gov.br/index.php/RevistadaFundarte/article/view/429/535.

Acesso em: 03 dez. 2018.

MINAYO, Maria Cecília de Souza (Org.). Pesquisa social: teoria, método e criatividade. 33를 ed. Petrópolis, RJ: Vozes, 2013.

MIRANDA, Simone da; BORGES, Maria Helena Jayme. A profissão de músico diante da diversidade nas possiblidades de atuação. Revista da Fundarte, Montenegro, ano 14, n. 27, jan./jun. 2014. Disponível em: http://seer.fundarte.rs.gov.br/index.php/RevistadaFundarte/article/view/56/141.

Acesso em: 03 dez. 2018.

MORAES, Patrick Aozani; RHODEN, Sandra. A educação musical e o ballet clássico. Revista da Fundarte, Montenegro, ano 17, n. 34, ago./dez. 2017. Disponível http://seer.fundarte.rs.gov.br/index.php/RevistadaFundarte/article/view/482/593.

Acesso em: 03 dez. 2018. 


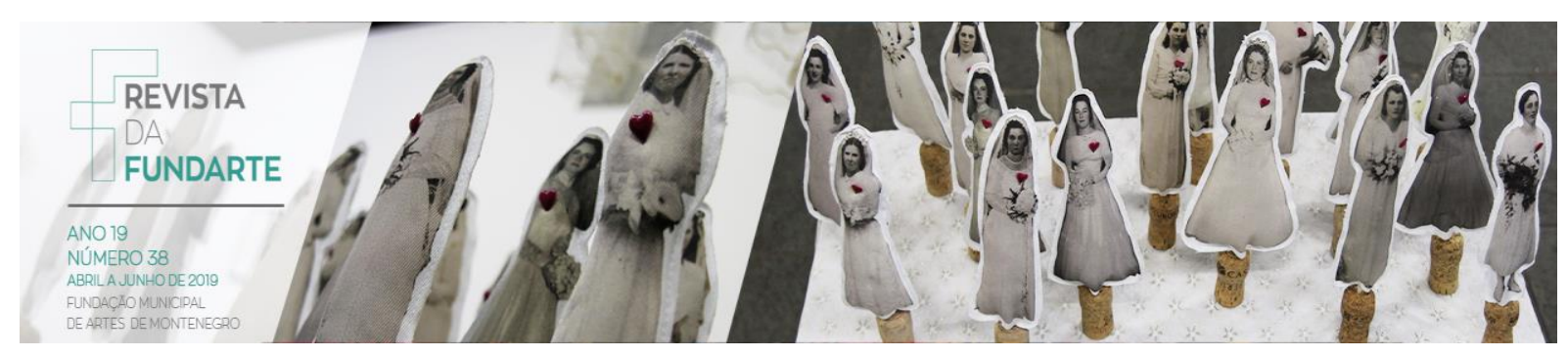

MORAES, Roque. Análise de conteúdo. Revista Educação, v. 22, n. 37, p. 7-32, Porto Alegre: $1999 . \quad$ Disponível em: https://edisciplinas.usp.br/pluginfile.php/4125089/mod resource/content/1/RoqueMoraes Analise\%20de\%20conteudo-1999.pdf Acesso em: 1 dez. 2018.

OLIVEIRA, Flávio. Música e universidade. Revista da Fundarte, Montenegro, v. 1, n. 2, jul./dez. $2001 . \quad$ Disponível em: http://seer.fundarte.rs.gov.br/index.php/RevistadaFundarte/issue/view/11. Acesso em: 03 dez. 2018.

OLIVEIRA, Tiago. O ensino particular de música e o tempo de lazer: um estudo de caso na perspectiva de três alunos adolescentes. Revista da Fundarte, Montenegro, ano 15, n. 30, jul./dez. 2015. Disponível em: http://seer.fundarte.rs.gov.br/index.php/RevistadaFundarte/article/view/318/427.

Acesso em: 03 dez. 2018.

PACHECO, Eduardo Guedes. Arte, diferença e educação - um manifesto sobre formação de professores de arte. Revista da Fundarte, Montenegro, ano 15, n. 30, jul./dez. 2015. Disponível em: http://seer.fundarte.rs.gov.br/index.php/RevistadaFundarte/article/view/323/428. Acesso em: 03 dez. 2018.

PEREIRA, Júlio Cesar Pires; NASCIMENTO, Flávia Marchi. O acordeom na educação musical: perspectivas para uma formação inicial no ensino superior. Revista da Fundarte, Montenegro, ano 13, n. 26, jul./dez. 2013. Disponível em: http://seer.fundarte.rs.gov.br/index.php/RevistadaFundarte/article/view/19/24. Acesso em: 03 dez. 2018.

PIRES, Nair; DALBEN, Angela Imaculada Loureiro de Freitas. Música nas escolas de educação básica: o estado da arte na produção da revista da Abem (1992-2011). Revista da ABEM. Londrina, v. 21, n. 30, jan./jun., 2013. Disponível em: http://www.abemeducacaomusical.com.br/revistas/revistaabem/index.php/revistaabe m/article/view/85/70 Acesso em: 13 dez. 2018.

PRASS, Luciana. Etnografias sobre etnopedagogias musicais. Revista da Fundarte, Montenegro, v. 5, n. 9, jan./jul. 2005. Disponível em: http://seer.fundarte.rs.gov.br/index.php/RevistadaFundarte/issue/viewlssue/19/39. Acesso em: 03 dez. 2018.

RAMBO, Zuleica Regina; ALMEIDA, Bruno Felix da Costa Almeida; WOLFFENBÜTTEL, Cristina Rolim. Educação musical na infância: uma investigação sobre sua importância. Revista da Fundarte, Montenegro, ano 19, n. 36, jul./dez. 2018.

Disponível em: http://seer.fundarte.rs.gov.br/index.php/RevistadaFundarte/article/view/495/741.

Acesso em: 03 dez. 2018. 


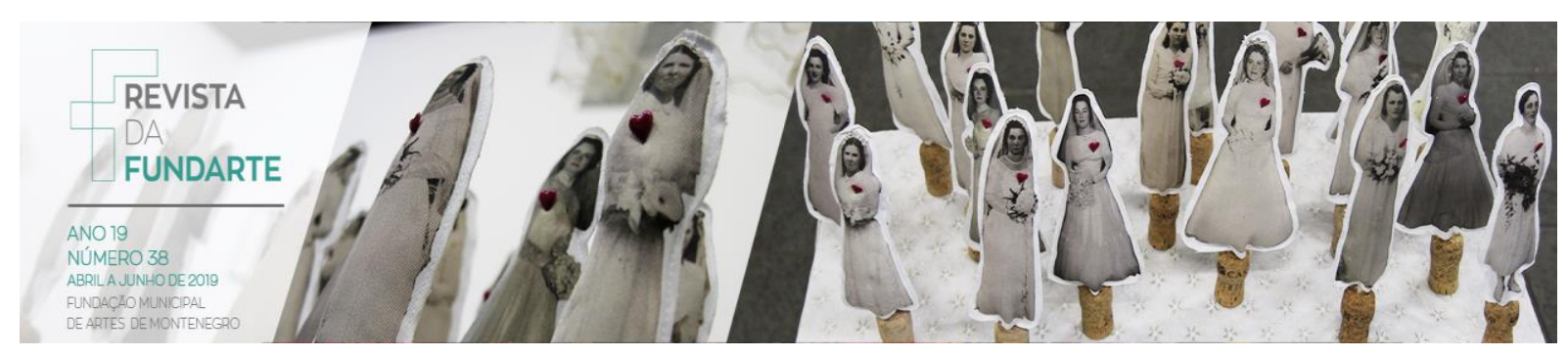

RASSLAN, Simone Nogueira; MAFFIOLETTI, Leda Albuquerque. A musicalidade na formação do ator: a produção de alguns pesquisadores brasileiros da última década. Revista da Fundarte, Montenegro, ano 13, n. 26, jul./dez. 2013. Disponível em: http://seer.fundarte.rs.gov.br/index.php/RevistadaFundarte/article/view/13/14. Acesso em: 03 dez. 2018.

RECK, André Müller. Identidades musicais na cultura gospel. Revista da Fundarte, Montenegro, ano 14, n. 27, jan./jun. 2014. Disponível em: http://seer.fundarte.rs.gov.br/index.php/RevistadaFundarte/article/view/34/143.

Acesso em: 03 dez. 2018.

REGGIORI, Márcio Bittencourt. Estágio supervisionado no hospital: um novo panorama de atuação e uma nova realidade na rotina das instituições de saúde. Revista da Fundarte, Montenegro, ano 17, n. 34, ago./dez. 2017. Disponível em: http://seer.fundarte.rs.gov.br/index.php/RevistadaFundarte/article/view/469/590.

Acesso em: 03 dez. 2018.

REIS, Jonas Tarcísio. A formação do educador musical no mundo hodierno: pensamentos necessários perspectivados na realidade brasileira. Revista da Fundarte, Montenegro, ano 10, n. 20, jul./dez. 2010. Disponível em: http://seer.fundarte.rs.gov.br/index.php/RevistadaFundarte/issue/viewlssue/6/6. Acesso em: 03 dez. 2018.

RHODEN, Sandra. Notação musical: inquietações da prática docente. Revista da Fundarte, Montenegro, ano 12, n. 23, jan./jun. 2012. Disponível em: http://seer.fundarte.rs.gov.br/index.php/RevistadaFundarte/issue/viewlssue/4/4. Acesso em: 03 dez. 2018.

ROMANOWSKI, Joana Paulin; ENS, Romilda Teodora. As pesquisas denominadas do tipo "estado da arte' em educação. Revista Diálogo Educ., Curitiba, v. 6, n. 19, set./dez., $2006 . \quad$ Disponível em: https://periodicos.pucpr.br/index.php/dialogoeducacional/article/view/24176/22872 Acesso em: 14 dez. 2018.

SABEDOT, Rodrigo. Escolas de música: uma revisão de literatura. Revista da Fundarte, Montenegro, ano 19, n. 36, jul./dez. 2018. Disponível em: http://seer.fundarte.rs.gov.br/index.php/RevistadaFundarte/article/view/491/740. Acesso em: 03 dez. 2018.

SACRAMENTO, Cristiane Duarte. Educação musical no ensino fundamental: uma visão compartilhada. Revista da Fundarte, Montenegro, ano 8, n. 15, jan./jun. 2008. Disponível http://seer.fundarte.rs.gov.br/index.php/RevistadaFundarte/issue/viewlssue/20/40. Acesso em: 03 dez. 2018. 


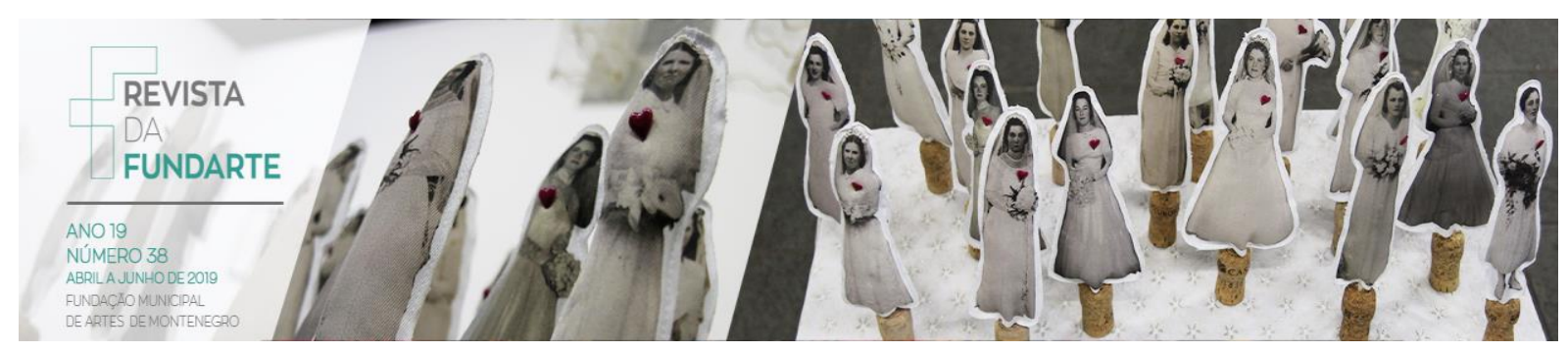

SALA, Helenea Dóris; LOURO, Ana Lúcia. Recitais didáticos: das memórias musicais e sonoridades midiáticas à ampliação da escuta musical. Revista da Fundarte, Montenegro, ano 12, n. 24, jul./dez. 2012. Disponível em: http://seer.fundarte.rs.gov.br/index.php/RevistadaFundarte/issue/viewlssue/35/58.

Acesso em: 03 dez. 2018.

SANTOS, Luiz Fernando Cardozo dos; BOZZETTO, Adriana. Trilha sonora dos jogos eletrônicos: uma análise da série Final Fantasy. Revista da Fundarte, Montenegro, ano 10, n. 19, jan./jun. 2010. Disponível em: http://seer.fundarte.rs.gov.br/index.php/RevistadaFundarte/issue/viewlssue/7/7.

Acesso em: 03 dez. 2018.

SANTOS, Regina Antunes Teixeira dos. Aspectos da prática reflexiva de solfejo na proposta de Davidson e Scripp. Revista da Fundarte, Montenegro, v. 3, n. 5, jan./jun. 2003.

Disponível

em:

http://seer.fundarte.rs.gov.br/index.php/RevistadaFundarte/issue/view/13. Acesso em: 03 dez. 2018.

SANTOS, Regina Antunes Teixeira dos. Investigação colaborativa: ferramenta potencial para o desenvolvimento profissional do professor de instrumento. Revista da Fundarte, Montenegro, ano 11, n. 21, jan./jun. 2011. Disponível em: http://seer.fundarte.rs.gov.br/index.php/RevistadaFundarte/issue/viewlssue/27/49.

Acesso em: 03 dez. 2018.

SCHEFFER, Ranielly Boff; WOLFFENBÜTTEL, Cristina Rolim. O projeto pedagógico do curso de Licenciatura em Música da UERGS: analisando-o a partir da legislação vigente e discutindo a proposta de formação inicial de professores de música. Revista da Fundarte, Montenegro, ano 15, n. 29, jan./jun. 2015. Disponível em: http://seer.fundarte.rs.gov.br/index.php/RevistadaFundarte/article/view/256/411.

Acesso em: 03 dez. 2018.

SITE DA REVISTA DA FUNDARTE.

http://seer.fundarte.rs.gov.br/index.php/RevistadaFundarte/index. Acesso em: 24 jan. 2019.

SOUZA, Jusamara. Currículos de música e cultura brasileira: mas, que concepções de cultura brasileira? Revista da Fundarte, Montenegro, v. 1, n. 1, jan./jun. 2001. Disponível

em: http://seer.fundarte.rs.gov.br/index.php/RevistadaFundarte/issue/view/10. Acesso em: 03 dez. 2018.

SOUZA, Jusamara; MATEIRO, Teresa; BELLOCHIO, Cláudia; KLEBER, Magali. Políticas de ação da ABEM para a Região Sul. Revista da Fundarte, Montenegro, v. 3, n. 5, jan./jun. 2003.2 Disponível em: http://seer.fundarte.rs.gov.br/index.php/RevistadaFundarte/issue/view/13. Acesso em: 03 dez. 2018. 


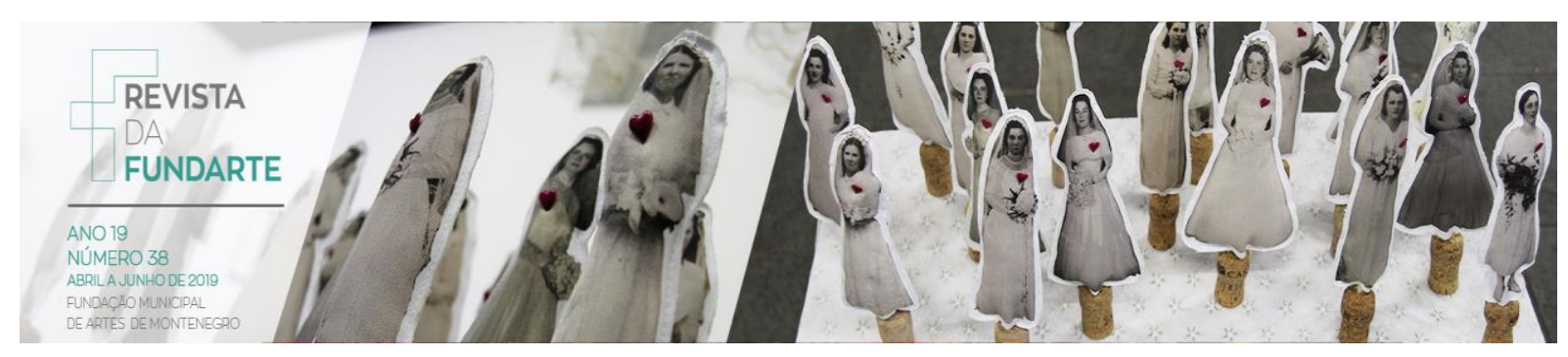

SOUZA, Marquessuel Dantas de. Literatura, música, geografia e educação: simbolismo cultural. Revista da Fundarte, Montenegro, ano 15, n. 29, jan./jun. 2015. Disponível http://seer.fundarte.rs.gov.br/index.php/RevistadaFundarte/article/view/254/412. Acesso em: 03 dez. 2018.

SOUZA, Marquessuel Dantas de. Literatura, música, geografia e educação: simbolismo cultural. Revista da Fundarte, Montenegro, ano 15, n. 29, jan./jun. 2015. Disponível http://seer.fundarte.rs.gov.br/index.php/RevistadaFundarte/article/view/314/415. Acesso em: 03 dez. 2018.

TORRE, Sylvia de la; PITTAU, Verónica. Una transposicíon plástico-musical: el caso de "El triunfo de la muerte" de Otto Dix/Ezequiel Diz. Revista da Fundarte, Montenegro, ano 15, n. 30, jul./dez. 2015. Disponível em: http://seer.fundarte.rs.gov.br/index.php/RevistadaFundarte/article/view/319/425.

Acesso em: 03 dez. 2018.

TORRES, Maria Cecília de Araújo R.. Entre temas e caminhos de pesquisa: escolhas de alunos de um curso de graduação em música Revista da Fundarte, Montenegro, ano 6, n. 11 e 12, jan./dez. 2006. Disponível em: http://seer.fundarte.rs.gov.br/index.php/RevistadaFundarte/issue/viewlssue/39/63.

Acesso em: 03 dez. 2018.

TORRES, Maria Cecília de Araujo Rodrigues. Contribuições dos cursos de Licenciatura em Música para a formação de pesquisadores: algumas ideias. Revista da Fundarte, Montenegro, ano 11, n. 22, jul./dez. 2011. Disponível em: http://seer.fundarte.rs.gov.br/index.php/RevistadaFundarte/issue/viewlssue/5/5.

Acesso em: 03 dez. 2018.

TORRES, Maria Cecília de Araújo Rodrigues. LEAL, Cláudia Maria Freitas. Reflexões de professoras supervisoras de estágios supervisionados de Música no ambiente hospitalar: desafios e aprendizagens. Revista da Fundarte, Montenegro, ano 13, n. 26, jul./dez. 2013. Disponível em: http://seer.fundarte.rs.gov.br/index.php/RevistadaFundarte/article/view/17/18. Acesso em: 03 dez. 2018.

TORRES, Maria Cecília de Araújo Rodrigues. Olhares de alunos de um curso de licenciatura em música: entre métodos e manuais para ensino de instrumentos. Revista da Fundarte, Montenegro, ano 9, n. 17, jan./jun. 2009. Disponível em: http://seer.fundarte.rs.gov.br/index.php/RevistadaFundarte/issue/viewlssue/15/35. Acesso em: 03 dez. 2018.

ULRICHM Ana Denise; RHODEN, Sandra; SCHÖELLKOPF, Suzana. Dança, música, artes visuais e teatro: reflexões sobre as práticas pedagógicas em sala de FUNDARTE: contribuições para o pensamento educativo-musical. Revista da FUNDARTE, Montenegro, p.117-163, ano 19, ํo 38, abril/junho de 2019.

Disponível em: http://.seer.fundarte.rs.gov.br/index.php/RevistadaFundarte/index> 28 de junho de 2019. 


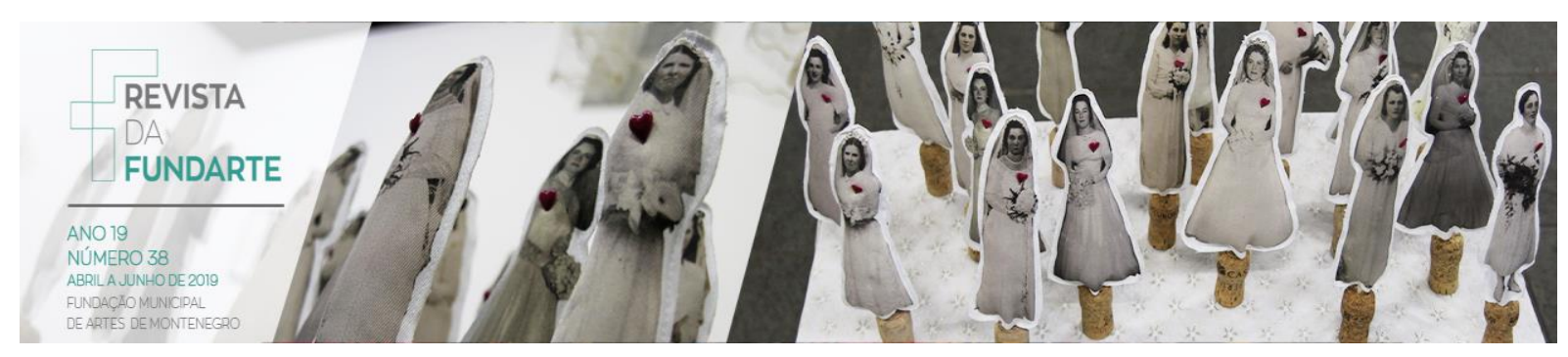

aula e o professor propositor. Revista da Fundarte, Montenegro, ano 14, n. 28, jul./dez. 2014.2 Disponível em: http://seer.fundarte.rs.gov.br/index.php/RevistadaFundarte/article/view/155/248.

Acesso em: 03 dez. 2018.

VALVERDE, Josemir. Identidade poética. Revista da Fundarte, Montenegro, ano 18, n. 35, jan./jun. 2018. Disponível em: http://seer.fundarte.rs.gov.br/index.php/RevistadaFundarte/article/view/475/605.

Acesso em: 03 dez. 2018.

WEISS, Douglas Rodrigo Bonfante; LOURO, Ana Lúcia de Marques e. Caminhos formativos de professores de acordeon: aportes teóricos a partir de narrativas. Revista da Fundarte, Montenegro, ano 13, n. 26, jul./dez. 2013. Disponível em: http://seer.fundarte.rs.gov.br/index.php/RevistadaFundarte/article/view/23/23. Acesso em: 03 dez. 2018.

WILLE, Regina Blanc. Adolescentes e música: uma investigação a partir de suas experiências formais, não-formais e informais. Revista da Fundarte, Montenegro, v. 3, n. 5, jan./jun. 2003.2 Disponível em: http://seer.fundarte.rs.gov.br/index.php/RevistadaFundarte/issue/view/13. Acesso em: 03 dez. 2018.

WOLFFENBÜTTEL, Cristina Rolim. A música na educação básica: reflexões a partir da legislação vigente e as possibilidades de trabalho nas escolas. Revista da Fundarte, Montenegro, ano 6, n. 11 e 12, jan./dez. 2006. Disponível em: http://seer.fundarte.rs.gov.br/index.php/RevistadaFundarte/issue/viewlssue/39/63.

Acesso em: 03 dez. 2018.

WOLFFENBÜTTEL, Cristina Rolim. A presença da música nos projetos políticopedagógicos das escolas e a importância das interlocuções entre as atividades musicais e a gestão escolar. Revista da Fundarte, Montenegro, ano 8, n. 15, jan./jun. 2008.

em:

http://seer.fundarte.rs.gov.br/index.php/RevistadaFundarte/issue/viewlssue/20/40.

Acesso em: 03 dez. 2018.

WOLFFENBÜTTEL, Cristina Rolim. Educação Musical, paradigmas de pesquisa e possibilidades de investigações. Revista da Fundarte, Montenegro, ano 12, n. 24, jul./dez. $2012 . \quad$ Disponível em: http://seer.fundarte.rs.gov.br/index.php/RevistadaFundarte/issue/viewlssue/35/58. Acesso em: 03 dez. 2018.

WOLFFENBÜTTEL, Cristina Rolim. Educação Musical: refletindo sobre o campo de estudo e os espaços de atuação profissional. Revista da Fundarte, Montenegro, ano $11, \quad n .21$, jan./jun. 2011. Disponível em: http://seer.fundarte.rs.gov.br/index.php/RevistadaFundarte/issue/viewlssue/27/49.

Acesso em: 03 dez. 2018. 


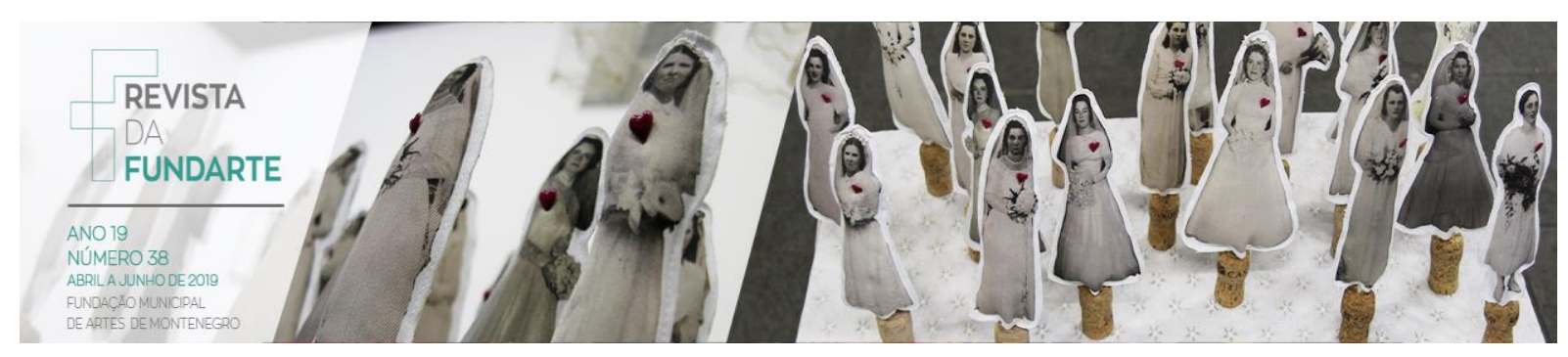

WOLFFENBÜTTEL, Cristina Rolim. ERTEL, Daniele Isabel. A inserção da música em escolas públicas dos municípios do Vale do Caí, RS. Revista da Fundarte, Montenegro, ano 14, n. 27, jan./jun. 2014. Disponível em: http://seer.fundarte.rs.gov.br/index.php/RevistadaFundarte/article/view/55/140.

Acesso em: 03 dez. 2018.

WOLFFENBÜTTEL, Cristina Rolim. Interlocuções entre folclore e educação. Revista da Fundarte, Montenegro, v. 5, n. 9, jan./jul. 2005. Disponível em: http://seer.fundarte.rs.gov.br/index.php/RevistadaFundarte/issue/viewlssue/19/39. Acesso em: 03 dez. 2018.

WOLFFENBÜTTEL, Cristina Rolim. Um estudo sobre as vivências folclóricomusicais de alunos do ensino fundamental. Revista da Fundarte, Montenegro, v. 4, n. $7,2004 . \quad$ jan./jun. Disponível em: http://seer.fundarte.rs.gov.br/index.php/RevistadaFundarte/issue/viewlssue/16/36. Acesso em: 03 dez. 2018.

WOLKMER, Juliana. Práticas políticas para além da cena contemporânea em tempos difíceis. Revista da Fundarte, Montenegro, ano 18, n. 35, jan./jun. 2018. Disponível em: http://seer.fundarte.rs.gov.br/index.php/RevistadaFundarte/article/view/476/606. Acesso em: 03 dez. 2018.

ZAMONNER, Jorge; ORMEZZANO, Graciela. Uma escola de samba por dentro: estudo de caso etnográfico. Revista da Fundarte, Montenegro, v. 5, n. 9, jan./jul. 2005. em: http://seer.fundarte.rs.gov.br/index.php/RevistadaFundarte/issue/viewlssue/19/39. Acesso em: 03 dez. 2018. 